\title{
Cetatea romană de la StÂnCA TOPAlu - CARiera „MARgela” (SAU „Mariella”). \\ DOSARUL ARHEOLOGIC PENTRU O MERITATĂ REPARAȚIE ISTORICĂ.
}

Ioan Carol Opriș, Cătălin Dobrinescu

\section{Rezumat}

În anul 2006 a fost realizat un sondaj în fortificația romană de la Stânca Topalu (com. Topalu, jud. Constanța) în vederea obținerii informațiilor stratigrafice.

Fortificația de la Stânca Topalu, conform informației istorice disponibile, este un castru ridicat de o unitate auxiliară, pe un promontoriu situat la $4 \mathrm{~km}$ Nord de satul Topalu. Fortificația romană avea o formă patrulateră cu laturi de cca 170 x 116 m, ruinele antice fiind vizibile la suprafaţă în anul 1890. Mare parte din latura de vest şi de nord au fost distruse de o veche carieră de piatră, astăzi râmând o suprafața de aproximativ 0,66 ha.

Autorii articolului valorifică toate datele cunoscute până în prezent despre fortificația de la Stânca Topalu. Noua documentare fotografică, realizată în cadrul Programului Naţional Limes, evidențiază nu doar sistemul defensiv, dar și un edificiu cu absidă (biserică?), amplasat la mică distanţă de jumătatea laturii de Sud. Toate aceste date, vor constitui foarte probabil punct de plecare pentru noi cercetări arheologice sistematice ale acestei fortificaţii.

Abstract (The Roman Fortress from Stânca Topalu, Quarry 'Margela' (or 'Mariella'). An archaeological file for a Historic Retrieval)

In 2006, a survey was carried out in the Roman fortification of Stânca Topalu (the 'Cliff Topalu', Topalu commune, Constanţa County) in order to g stratigraphic information.

The Stânca Topalu Fort, according to the available historical information, is most likely a fort built by an auxiliary unit, on a promontory located $4 \mathrm{~km}$ North of Topalu village. The Roman fortification had a quadrilateral shape with sides of about $170 \times 116 \mathrm{~m}$, the ancient ruins being visible on the surface in 1890 . Most of the western and northern sides were destroyed by an old stone quarry, today it preserves only an area of approx. 0.66 ha.

The authors of the article make use of all the known data on the fortification of Stânca Topalu. The new photographic documentation, made within the Limes National Program, highlights not only the defensive system, but also an edifice with an apse (church?), located at a short distance from the south precinct. All these data will very likely be the starting point for new systematic archaeological investigations of this fortification.

Cuvinte cheie: limes, fortificație romană târzie, Scythia, Dunărea de Jos, aero-fotogrametrie

Keywords: limes, Late Roman fort, Scythia, Lower Danube, aerial photogrammetry 


\section{INFORMAȚIA ISTORICĂ}

În perioada 15-31 iulie 2006 (potrivit autorizaţiei de evaluare de teren nr. 10/ 2006, eliberată de MCC la 12.07.2006) se desfășurau săpături arheologice în punctul Stânca Topalu (com. Topalu, jud. Constanţa). Colectivul cercetării a fost format atunci din dr. Cătălin Dobrinescu (MINAC) și dr. Ioan Carol Opriş (Universitatea din Bucureşti), cărora li s-au alăturat studenţi ai Universităţii „Ovidius” din Constanţa. Rezultatele acestei cercetări preliminare au fost ulterior publicate în paginile Cronicii Cercetărilor Arheologice din România ${ }^{1}$. Scopul acestei evaluări de teren, în timpul căreia a fost practicată o secţiune de mici dimensiuni în cetatea antică - S I/ 2006, era tocmai acela de a obține primele date reale de natură stratigrafică şi cronologică ale monumentului. Micul sondaj stratigrafic în fortificaţia romano-bizantină de la Stânca Topalu a fost realizat după ce în campaniile anterioare fuseseră deja recoltate fragmente ceramice romano-bizantine şi hallstattiene (de tip Babadag II) din submalurile botului de deal, pentru conturarea repertoriului de aşezări din hinterlandul Capidavei.

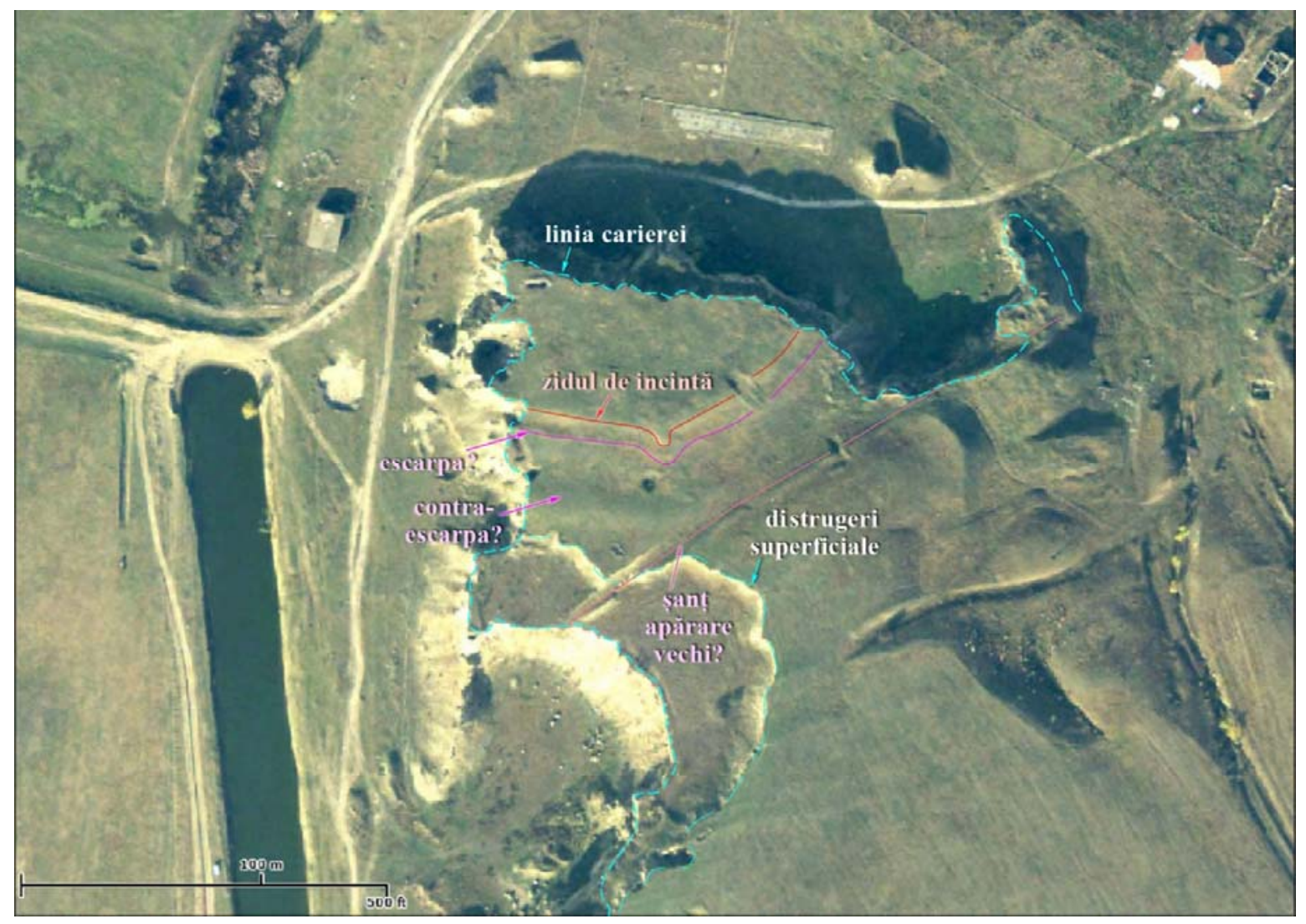

Figura 1. Stânca Topalu, Ortofotoplan ANCPI, 2012, cu poziţionarea fostei cariere de piatră şi a cetăţii.

În contextul cercetărilor de teren (periegheze) din anii respectivi în territorium Capidavense ${ }^{2}$ ne-am îndreptat atenţia şi asupra acestui important punct arheologic. Obiectivul principal al săpăturii din 2006 a fost realizarea unui sondaj stratigrafic, respectiv verificarea succesiunii straturilor romane şi hallstattiene. Timpul scurt şi numărul redus de lucrători afectaţi acestei operaţiuni au permis doar realizarea un mic sondaj de $2 \times 8 \mathrm{~m}$, orientat N-S, pe latura mică, în apropierea malului erodat. Suprafaţa rămasă din această fortificaţie este astăzi de aproximativ 0,66 ha, mare parte din latura de vest şi de nord fiind distruse de vechea carieră (Figura 1). După evaluarea însemnărilor și schițelor păstrate de la Pamfil Polonic putem aprecia suprafața generală a cetății pe care acesta a putut-o documenta în ultimul deceniu

\footnotetext{
${ }^{1}$ Dobrinescu, Opriș 2007.

${ }^{2}$ Vezi Opriș, Ștefan, Duțescu 2008.
} 
al veacului al XIX-lea undeva în jurul a 1,75 ha, poate chiar spre $2 \mathrm{ha}^{3}$. Cetatea a fost construită pe un masiv de calcar înalt de $40 \mathrm{~m}^{4}$, care oferea în antichitate o bună vizibilitate înspre Carsium; în Charta României Meridionale (1864) apare figurat pintenul de stâncă pe partea sudică a văii Scârția (Cekirgea), care se oprește într-un braț al Dunării, în dreptul ostrovului Aternați (Atârnați) (Figura 2). Planul Director de Tragere al Armatei Române nu oferă, din păcate, date suplimentare relevante pentru studiul cetății ${ }^{6}$, cu excepția faptului că figurează o carieră Minaveli (?), la capătul văii Cekirgea (Cichirgeana). (Figura 3).
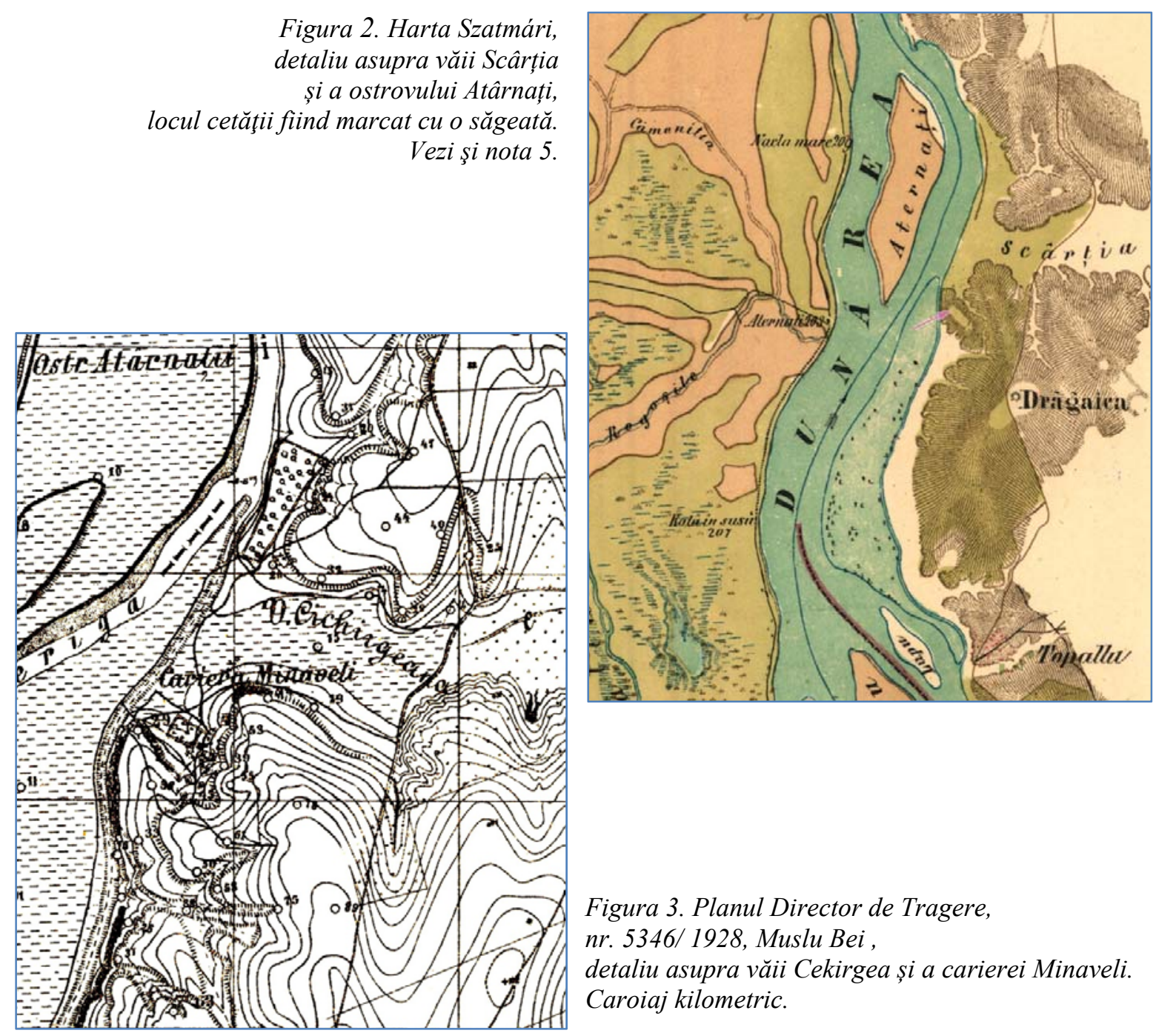

Privitor la fortificația de la Stânca Topalu, informația istorică disponibilă amintește un castellum pentru o unitate auxiliară, situat pe un promontoriu, la $4 \mathrm{~km}$ nord de satul Topalu. Aici se mai vedeau la 1890 numeroase urme ale ruinelor antice (Figura 4). Fortificația avea o formă patrulateră cu laturi de cca $170 \mathrm{x}$ $116 \mathrm{~m}$, potrivit lui Grigore Tocilescu și Pamfil Polonic, fiind dublată de un vallum larg de $10 \mathrm{~m}$ și înalt de $1 \mathrm{~m}$ (din care se mai poate distinge astăzi un traseu lat de $20 \mathrm{~m}$ și adânc de 2-3 m, respectiv șanțul) ${ }^{7}$. Două porți vor fi funcționat pe latura de est. Latura de sud măsura $116 \mathrm{~m}$, cea de est $140 \mathrm{~m}$, cea de nord $104 \mathrm{~m}$,

\footnotetext{
${ }^{3}$ Pentru o evaluare a suprafeței cetății romane de la Topalu la cca 1.5 ha, vezi Anexa II, documentul nr. 2/ copie Nr. 59/ 1927, reprezentând o scrisoare adresată de către Ioan Andrieșescu, directorul MNA Președintelui Comisiunii Monumentelor Istorice, Nicolae Iorga.

${ }^{4}$ Polonic 1935, 22.

${ }^{5}$ Vezi Opriș 2018a, 61, n. 5: http://charta1864.gis-it.ro/charta.html, Col. XIII/ Ser. 6.

${ }^{6}$ Muslu Bei 5346. Menționează că ridicarea topografică în teren s-a făcut în 1883-1884 şi ,partea de sud, reprodus după reambularea anului 1913" (tipărit de Serviciul Geografic al Armatei în 1928).

${ }^{7}$ Gudea 2005, 448-449, Nr. 41.
} 
iar cea de vest, cea mai mare, nu mai puțin de $170 \mathrm{~m}^{8}$. Grigore Florescu a realizat o cercetare sumară la Topalu (în 1924 sau 1927?), la capătul căreia concluzionează că sistemul de construcție al paramentului exterior este foarte asemănător celui întâlnit deja la cetățile de la Seimeni și la Capidava. Curent utilizat din secolul al IV-lea p.Chr, acesta presupunea distribuirea unor blocuri de calcar de mici dimensiuni (variind între $15 \times 15 \mathrm{~cm}$ și $30 \times 30 \mathrm{~cm}$ ) sub forma unor asize așezate cu grijă pentru păstrarea orizontalei și care imită oarecum opus quadratum. ${ }^{9}$

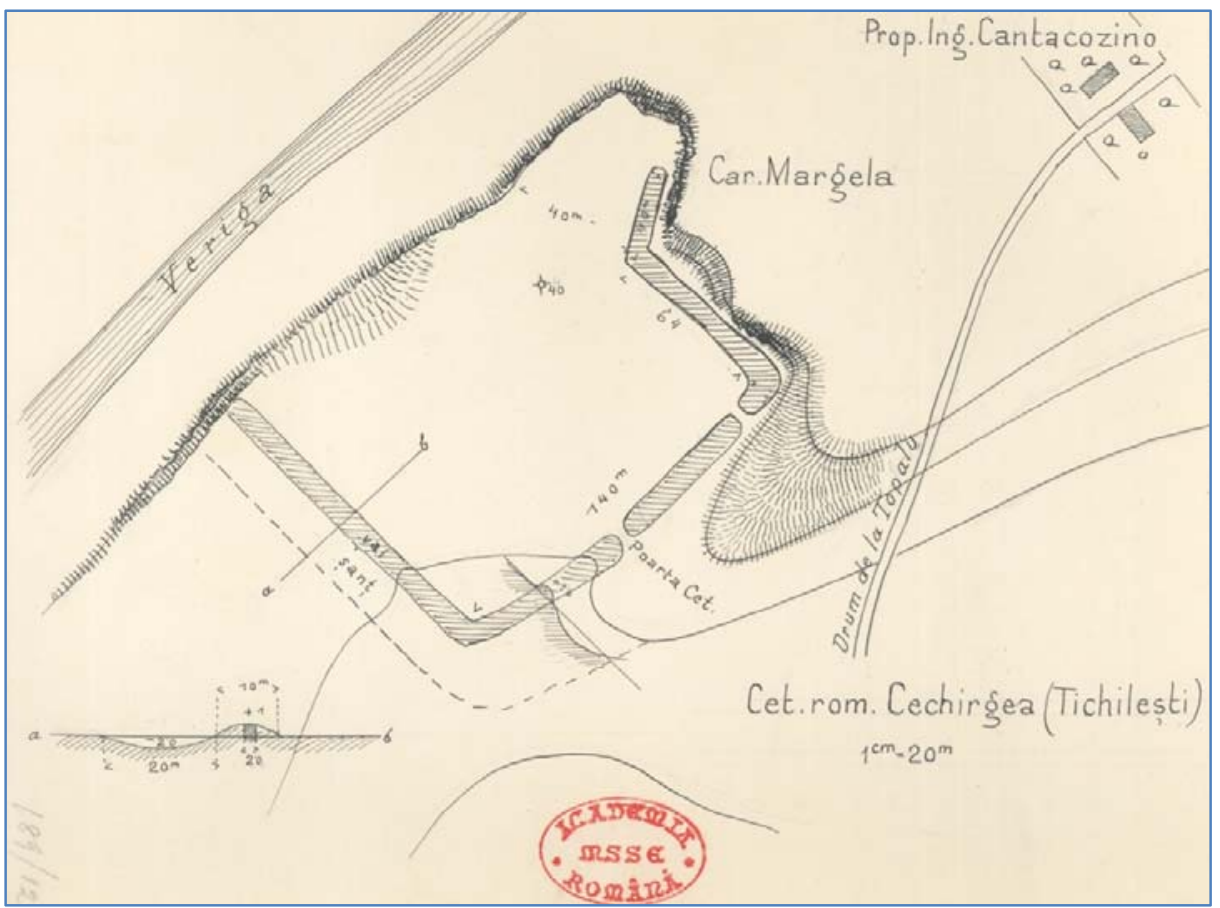

Figura 4.

Planul cetății de la Stânca TopaluPamfil Polonic, Mss. Academia Română Cabinetul de Manuscrise și de Carte Rară, $n r$. $189 / 12$.

Orientare aprox. NV.

De la Topalu erau cunoscute la vremea publicării ISM V două epigrafe: niciuna nu a fost însă identificată în situl de la Cekirgea/ Cariera Margela. Una dintre aceste piese, o stelă funerară fragmentară, a fost găsită în sat, iar cea de-a doua, un altar dedicat lui Iupiter, Iunonei și zeiței Ceres (Frugifera) la jumătatea distanței dintre Gălbiori și Stupina, pe traseul DN 2 A/ E $60^{10}$. În 1980, iar apoi în 2013, trei noi piese au fost găsite la Topalu. În 1980, cu ocazia lucrărilor agricole la est de vatra satului au apărut două borne miliare, foarte probabil în apropierea poziției iniţiale, pe via militaris. Acestea sunt datate în vremea lui Septimius Severus și Caracalla (când guvernator este Caius Ovinius Tertullus, 198-201 p.Chr.), respectiv în timpul lui Aurelian (270-275), când provincia se găsește sub comanda lui Sallius Aristaenetus ${ }^{11}$. Identică este și datarea miliarului găsit în 2013, care îl menționează pentru a doua oară pe acest guvernator prea puțin cunoscut, cu unica observație că piesa se afla în poziție secundară, fiind extrasă din gardul unui sătean din Topalu. Unica piesă care provine, totuși, de la cetatea suprapusă mai târziu de Cariera Margela rămâne un relief din calcar de 0.45 x 0.74 x $0.25 \mathrm{~m}$, cu reprezentarea Cavalerului Trac ${ }^{12}$ (Figura 5). Într-o notă din Archäologischer Anzeiger (1914) dedicată descoperirilor din anul precedent, în care apare pentru prima dată semnalată piesa figurată de la Topalu, Vasile Pârvan amintește și zidurile unei construcții romane din cărămidă la baza masivului pe care stătea cetatea de la Topalu, documentată la rându-i cu o mărturie fotografică ${ }^{13}$ (Figura 6).

\footnotetext{
${ }^{8}$ Zahariade, Gudea 1997, 79; ISM V, 76.

${ }^{9}$ Florescu 1927-1932, 484, n. 2; 495.

${ }^{10}$ ISM V, nr. 55-56. Vezi și Munteanu 1975, 394-395 (nr. 3), care considera că este posibil ca piesa respectivă să provină, totuși, de la Capidava.

${ }^{11}$ Opriș 2018b, 161-163.

12 Pârvan 1914, col. 430; publicarea propriu zisă a piesei aparține lui Teodorescu 1915, 15-16 (nr. 37 ); ISM V, 76.

13 Pârvan 1914, col. 430-431 și Abb. 2: ".... Ferner wurden bei Topalu, südlich vom alten Carsium, die Fundamente eines mächtigen römischen Ziegelbaues (Abb. 2) und zwei parallele, dicht nebeneinanderlaufende Kanäle
} 

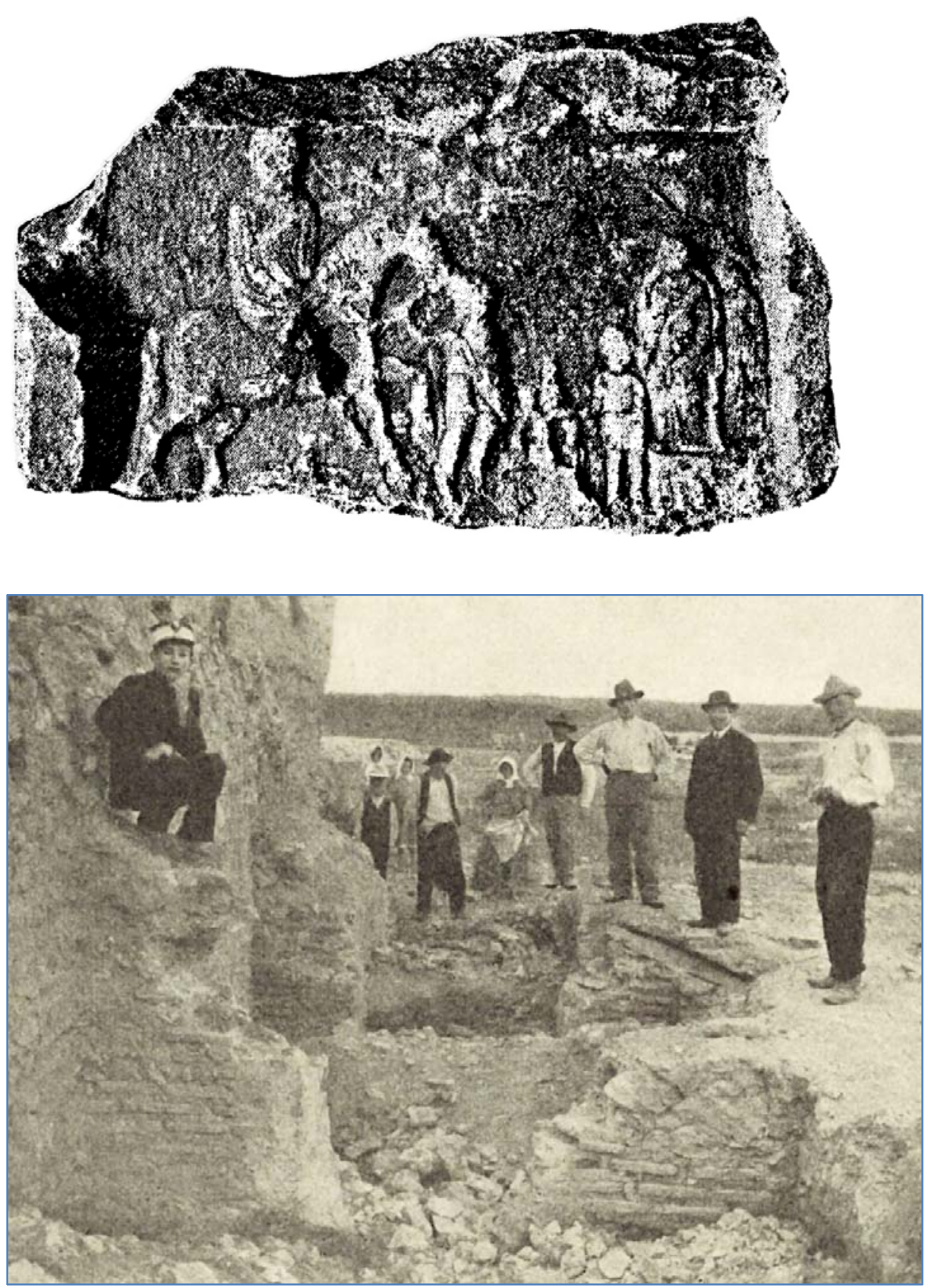

Figura 5.

Relief descoperit la Stânca Topalu. Prelucrare după Teodorescu 1915, 15-16, nr. 37.
Figura 6.

Construcție romană din cărămidă la baza masivului de la Stânca Topalu 1913 (după Pârvan 1914, col. 431, $A b b .2)$.

Despre funcționarea carierelor Statului pe teritoriul comunei Topalu avem informații încă din anul 1884, iar rolul acestora în obținerea materialului necesar pentru construcția podului Regele Carol I de la Cernavoda ori pentru obținerea pietrișului necesar la terasamentele căilor ferate și șoselelor dobrogene este iarăși de notorietate ${ }^{14}$.

Câteva decenii mai târziu, într-un raport adresat Ministrului Instrucțiunii Publice la 18 aprilie 1914, Vasile Pârvan reclama funcționarea unei cariere care afecta monumentul.

aufgedeckt, die aber von den Stellvertretern des Terraineigentümers fast vollständig demoliert worden waren, bevor wir eine vollständige Aufnahme davon hätten machen können: es sind dies nämlich Bauten, die zum römischen Kastell und vicus von Topalu gehören und wie die ganze Anlage - die auf einem Kalksteinfelsen über der Donau gelegen ist - noch jetzt, trotz aller Proteste von seiten des Nationalmuseums, als Steinbruch dienen;...”.

${ }^{14}$ Opriș 2018a, 63. 
„,... Pe teritoriul comunei Topalu, plasa Hârşova, la punctul numit Cekirgea, se exploatează actualmente o carieră de piatră pentru fabrica de ciment Cantacuzino din Brăila. Și cu această ocazie se distruge altă cetate antică așezată direct deasupra carierei. S-a distrus până acum latura de nord-vest, cum și câteva construcții antice de la poalele platoului cetății dinspre nord și nord-est. Și aici numita fabrică a căpătat concesie pe timp de 30 de ani-din care mai are încă 10 - iarășsi fără știrea autorităților competente. Deși se știa de existența cetății incă cu mult inainte..." 15

Ne apare relativ clar faptul că datele cuprinse în acest raport reprezintă o actualizare corespunzătoare a unei informații mai vechi, de foarte bună calitate, redactată la vremea când Pamfil Polonic vizitează și desenează un plan de situație al cetății. Momentul rămâne unul neprecizat, dar operațiunea trebuie să se fi petrecut cândva în ultimul deceniu al sec. XIX - începutul sec. XX, pe când începe să funcționeze cariera Margela (sau Mariella), operată de un antreprenor care exploata în mod similar masivul de calcar de aici, așa cum frații Ghenciu o făceau pe stânca cetății de la Capidava ${ }^{16}$.

Lipsesc informații pentru întreg deceniul următor, dar știm că Grigore Florescu studiază sumar paramentul cetății de la Topalu, poate în 1924, în timpul primei campanii de săpături arheologice la Capidava ${ }^{17}$. În tot cazul, cetatea romană de la Topalu era mai bine de jumătate distrusă de cariera de piatră care opera acolo, atunci când Gr. Florescu încearcă în 1927 să intre în sit. Ultima informație (în sens cronologic) referitoare la soarta cetății de la Stânca Topalu aparține aceluiași neobosit Pamfil Polonic, în paginile revistei Natura (1935), unde publică un articol intitulat Cetățile antice de pe malul drept al Dunării (Dobrogea) până la gurile ei ${ }^{18}$. Paragraful referitor la subiectul tratat aici se încheie cu dezarmanta constatare a marelui topograf: "... nu se respectă nicăeri legea monumentelor".

Corespondența oficială pe care acesta o va declanșa prin scrisoarea adresată direcțiunii Muzeului Național de Antichități la 3 august 1927 (vezi Anexa II) și în care vor fi implicate mai întâi Comisiunea Monumentelor Istorice, iar apoi Ministerul de Interne - Direcțiunea Administrației Generale, Contenciosului și Statisticii și Ministerul Industriei și Comerțului - Direcțiunea Generală a Minelor ${ }^{19}$ demonstrează pe deplin dramatismul situației. Negarea existenței unei cetăți la Topalu - Cekirgea venind din partea Ministerului de Interne, insuficient și în chip eronat informat, măsurile luate de Ministerul Industriei și Comerțului, comunicate prin adresa 88843/17 noiembrie 1927 către Comisiunea Monumentelor Istorice, prin care, în conformitate cu prescripțiunile art. 70 din Legea Minelor, este ,împiedecată extragerea de materiale din vechea cetate romană dela Topalu, instituindu-se o zonă de protecție de 20 m", dimpreună cu incriminarea lui Grigore Florescu într-o adresă a Direcțiunii Generale a Minelor, pe nedrept acuzat că ,vinde piatra extrasă de la descoperirea cetății”", ne pun în fața unei situații ale cărei ecouri nedorite le mai putem întâlni și astăzi. În ciuda progreselor indiscutabile în materie de protecție a patrimoniului arheologic, apărat în acest moment prin instrumente ca Repertoriul Arheologic Naţional sau Lista Monumentelor Istorice, putem inventaria probleme legate de lentoarea, ineficienţa sau chiar lipsa comunicării între instituțiile majore ale statului, o nepermisă uşurință în tratarea acestei resurse publice neregenerabile prin raport cu interese private, în sfârșit ignorarea legii sau nesancționarea riguroasă a celor care o încalcă cu sau fără voie.

\footnotetext{
15 Opriș 2014, 207.

${ }^{16}$ Vezi Anexa I, cu textul lui Pamfil Polonic, Cercetările de la Hârşova până la Ostrov (Silistra), din Mss. păstrate la Academia Română, Cabinetul de Manuscrise și Carte Rară, p. 4-5.

17 Vezi Florescu 1927-1932, 495. Pare mai puțin probabil ca aceste observații să fi fost obținute în 1927, cu ocazia evenimentelor prezentate în corespondența oficială din Anexa II, atunci când Gr. Florescu încearcă, fără succes, să viziteze situl roman de la Stânca Topalu.

18 Polonic 1935, 21-22: "La 4 km spre N de comuna Topalu, pe malul stâng al văei Cechirgea se află pe o stâncă înaltă $(40$ m) un castru roman de piatră cu forma pătrată. În partea de nord se distruge cetatea prin cariera Margela care scoate piatră de aci pentru o fabrică de ciment din Brăila. Lucrătorii carierii au găsit aci multe lucruri antice: vase, monete, etc. În interiorul cetăței se văd urme de construcții vechi. Cred că astăzi nu mai există această cetate căci deși declarată ca monument istoric, nefiind supravegheiată a fost dărâmată. În timpul când am fost la cadastrul țărei am intervenit să nu se împartă la țărani cetatea romană de lângă Gara Răcari, lângă Filiaş, dar în zadar, ea a fost parcelată. La Câmpulung se distruge o cetate mare romană de piatră numită Jidava, printr'o mină de cărbuni etc. nu se respectă nicăeri legea monumentelor".

${ }^{19}$ Mulțumim pe această cale Institutului de Arheologie al Academiei Române din București și Arhivei Muzeului Național de Antichități pentru accesul la această corespondență păstrată în volumul aferent anului 1927.
} 
Pe lângă informația istorică pe care încearcă să o consolideze contribuția noastră, prin adunarea tuturor datelor disponibile în acest moment asupra subiectului, articolul are și o menire reparatorie, de restabilire a informației istorice, așa cum pe bună dreptate o formulaseră Pamfil Polonic, Vasile Pârvan, iar mai apoi Grigore Florescu. În fond, acest articol constituie cea mai potrivită cale de răspuns la adresa No. 29795 din 17 noiembrie 1927, prin care Direcțiunea Administrației Generale, Contenciosului și Statisticii din cadrul Ministerului de Interne, la capătul unei "anchete" a prefectului județului Constanța și pretorului plășii Hârșova din 12 0ctombrie 1927, întocmește un răspuns Ministrului Cultelor și Artelor și direcțiunii Muzeului Național de Antichități, prni care concluzionează că "pe tot perimetrul concesiunii carierelor de piatră din Topal nu se găsește nici o cetate romană, sau vre-un monument istoric".

\section{SĂPĂTURA DE DIAGNOSTIC}

Așa cum arătam în rândurile de mai sus, sondajul stratigrafic din 2006 își propunea verificarea succesiunii straturilor romane şi hallstattiene. Amploarea acestuia a fost una redusă, motivaţia fiind legată de resursele financiare modeste și mai ales de lipsa acută a lucrătorilor, rezumându-se la o secțiune de 8 x 2 m, orientată Vest-Est, în apropierea malului erodat de nord (Figurile 7-9).
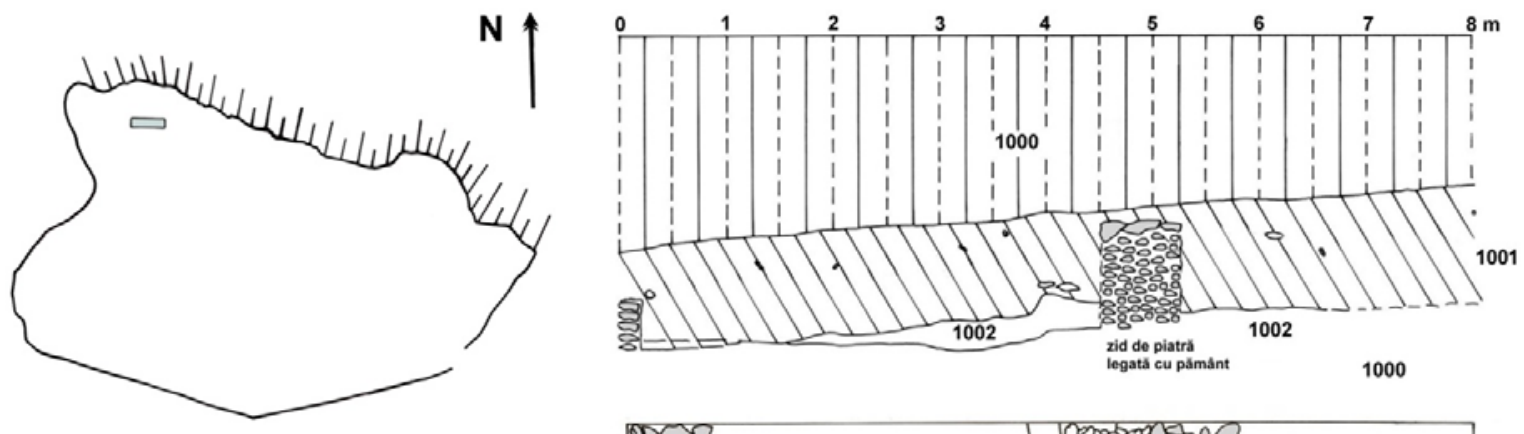

Figura 7. Stânca Topalu, schiță de plan cu amplasarea S.I/2006 (sus).

Figura 8 .

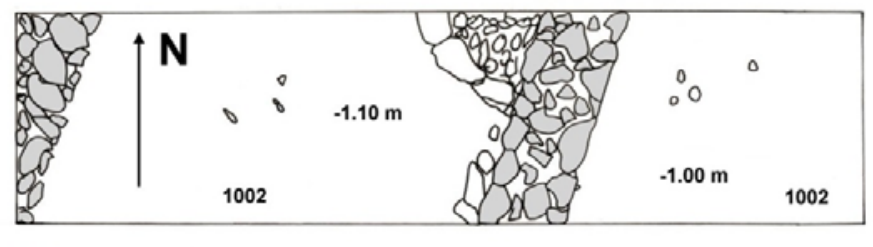

\&on zid de piatră legată cu pământ

1000 nivel vegetal 1002 nivel de distrugere sec. V/ VI p.Chr.

Stânca Topalu, secțiunea SI/2006, profil de sud și plan (dreapta).

Adâncimea la care a ajuns săpătura din 2006 este de $-1,10$ m, situaţia stratigrafică surprinsă fiind următoarea:

- vegetal (U.S. 1000): 0 la $-0,40 \mathrm{~m}$, sol de culoare brună, cenuşoasă, străpuns de gropi de crotovine, cu pietre şi fragmente mici de ţiglă;

- abandon (U.S. 1001): -0,40 la $-0,90$ m, nivel de abandon, cenuşos ca textură şi culoare, ce conţine pietre şi ţigle, fragmente ceramice romano-bizantine (castroane şi amfore, sec. V-VI p.Chr.) şi intrusive (slave ?);

- distrugere (U.S. 1002): sol brun-roşcat, cu arsură de lemn, aspect fărâmicios datorat arderii, chirpici ars, fragmente ceramice din a doua jumătate a sec. V- sec. VI p.Chr. (?), pietre şi oase de animale; reprezintă ultimul nivel de locuire al fortificaţiei romane târzii sau romano-bizantine. 


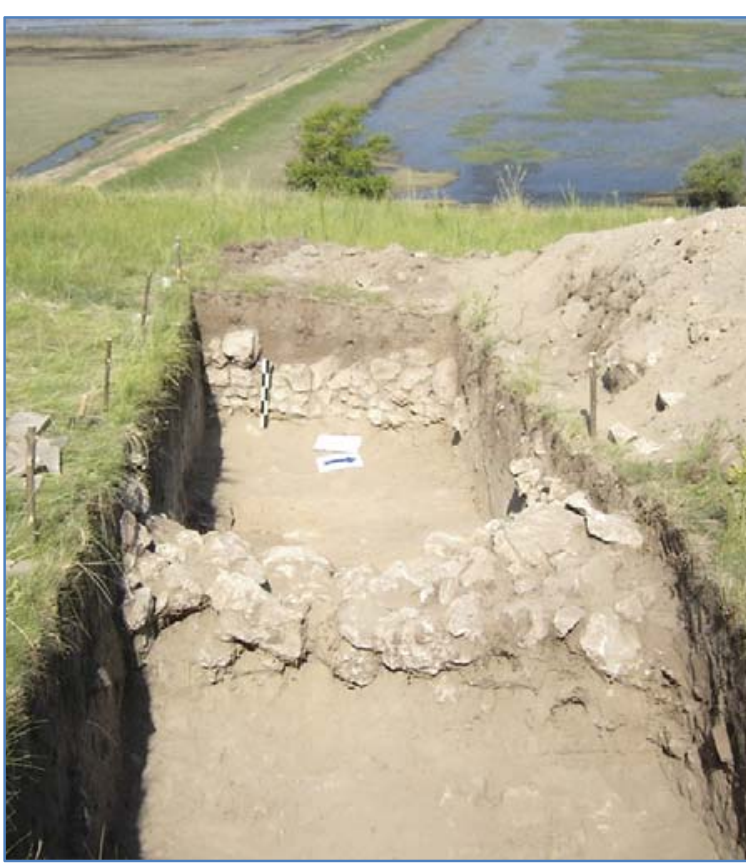

Figura 9. Stânca Topalu, secțiunea SI/2006, vedere spre vest.

Ultimelor unităţi stratigrafice le corespunde două ziduri din piatră $(\mathrm{Z} 1, \mathrm{Z} 2)$ legate cu pământ ale unei/unor(?) clădiri, surprinse însă doar la nivelul fundației (Figura 8). Acestea sunt ușor deviate de la aliniamentul N-S, dar poate fi remarcată și orientarea asemănătoare cu cea a clădirii cu absidă din apropierea laturii de sud (vezi infra). Materialul arheologic recoltat din U.S. 1002 constă din vase de bucătărie sparte in situ, fragmente de amfore, fusaiole, oase de animale, o monedă bronz ${ }^{20}$, acoperite de ţiglele şi pietrele construcţiei/construcțiilor menţionate (Figura 10). Până acum, potrivit datelor numismatice cunoscute, cele mai târzii monede cunoscute de la cetatea Topalu datau din epoca lui Honorius ${ }^{21}$, iar piesa descoperită în 2006 putea circula şi mai târziu, în secolul al VI-lea. Nu ar fi de prisos să amintim şi prezența în zonă a unei piese excepționale - un solidus emis la Constantinopol de la Theodosius al II-lea, datat 441-450 p.Chr., descoperit la cca $5 \mathrm{~km} \mathrm{NE}$ de Topalu ${ }^{22}$. În actualul stadiu al cercetărilor este imposibil să avansăm o limită finală clară pentru funcţionarea fortificaţiei de la Topalu. Din analiza materialului ceramic recoltat în timpul evaluării realizate în 2006 (veselă de masă microasiatică - castroane de tip LRC/ Phocean Ware Hayes $3^{23}$ şi amfora ,în formă de morcov”24) se poate avansa ideea că aceasta funcţiona cândva în cursul secolului V - începutul sec. VI p.Chr. (Figurile 11-12). Apoi, se remarcă şi materialul ceramic de factură „barbară”, constituit din oale-borcan lucrate cu mâna şi decorate cu alveole pe toată lungimea buzei, care seamănă foarte bine cu materialul descoperit la Capidava în Corpul de Gardă ${ }^{25}$, ultimul datat în sec. VI p.Chr. Acest tip de material are analogii foarte bune în Câmpia Română, la o distanță de 100-150 km de limes: Eugen S. Teodor leagă piesele ,arhaice” de la Capidava de barbarii recrutați pentru apărarea limesului de pe malul stâng, după ce se va fi depășit zona de siguranță, acel „safety no-man's land". ${ }^{26}$ Același tip de raționament ar putea fi acceptat și pentru apăătorii cetății imediat învecinate, cea de la Stânca Topalu. Din nefericire, nu au putut fỉ recoltate decât foarte puține fragmente,

\footnotetext{
${ }^{20}$ Monedă de la Constantius II (337-361), descoperită la Stânca Topalu 2006, $\square$ 3, US 1002: AE3, Constantinopol ? AE $\downarrow 2.0$ gr., 16 x 19 mm, ruptă. RIC, VIII, 149, anii 355-361 p.Chr.

${ }^{21}$ Barnea 1991, 182, n. 125; vezi şi TIR, L 35, 73.

${ }^{22}$ Dima, Popescu 2005, 369, 373, nr. 24. Mulțumim colegului Gabriel Talmațchi pentru semnalare.

${ }^{23}$ Cele câteva fragmente de castroane foceene, din care s-a păstrat puțin mai mult decât buza decorată à la roulette aparțin după toate probabilitățile tipului LRC/ Phocean Wares Hayes 3, variantele D-F, de datat larg între a doua jumătate a sec. V - primele decenii ale sec. VI p.Chr: Hayes 1972, 333-335, fig. 68-69; ATLANTE I, 232, Tav. CXII.5-11; CXIII.1-2.

${ }^{24}$ Piesa are următoarele dimensiuni: h. $29 \mathrm{~cm}$; dmax 15.5-16 cm. Pasta de factură inferioară, arsă incomplet, se exfoliază. Faptul că nu se păstrează gâtul și gura s-ar putea datora modului de deschidere, prin retezare. Pentru moment, proveniența este incertă. Potrivit lui Andrei Opaiţ (Toronto), care a prelucrat ceramica de la Chersones, piesa ar putea fi de proveniență nord-pontică, produsă poate într-un atelier lângă marea cetate romano-bizantină din Crimeea. Specialistul citat plasează circulaţia acestor amfore-morcov în sec. IV-V p.Chr. în bazinul pontic. Vezi şi Paraschiv 2006, 28-33, 48-49, pl. 7, nr. 48 (tip 8, varianta C), pentru amforele sinopeene înrudite morfologic cu cea descoperită la Topalu. Amfora de la Topalu-Cekirgea s-ar plasa mai repede în intervalul cronologic cuprins între sf. sec. IV - începutul sec. VI, deşi asemenea piese sunt raportate ca fiind în circulaţie chiar până în sec. următor.

${ }^{25}$ Vezi Opriş 2003, capitolul II.4 Vesela de bucătărie (vasa coquinatoria), în special subcapitolul II.4.6. Oale de bucătărie modelate cu mâna şi pe roata lentă (sec. VI p.Chr.), 102-113.

${ }^{26}$ Teodor 2010, 220; Topoleanu, Teodor 2009, 354, $361=$ fig. 5.
} 
buze decorate cu brâu de alveole (impresiuni realizate cu degetul în pasta crudă) ${ }^{27}$; nimic mai mult nu se poate spune legat de morfologia vaselor respective (Figura 13).
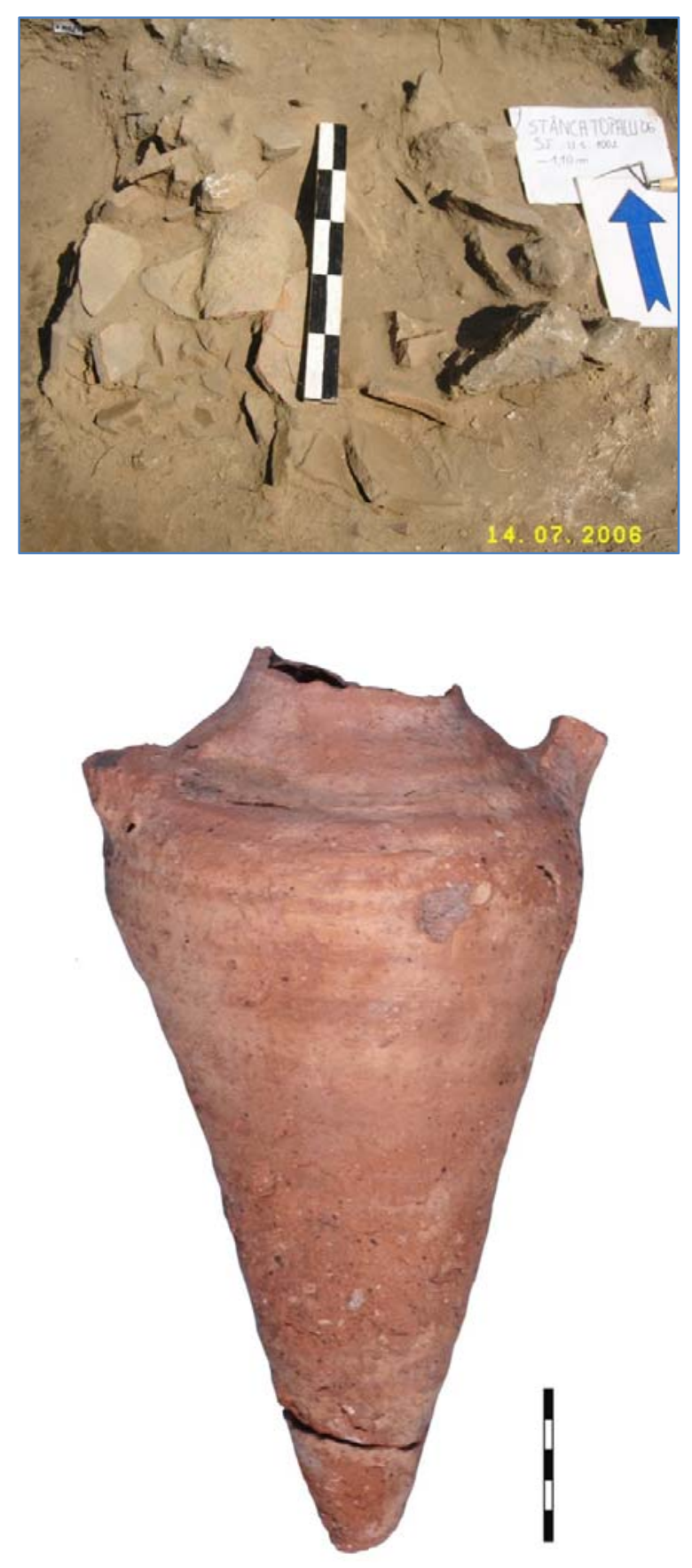

Figura 10. Stânca Topalu, secțiunea SI/2006.

Dărâmătură de cărămidă și piatră in situ.

Figura 11.

Fragmente din castroane de tip Late Roman C/

Phocean Ware 3 (jos).

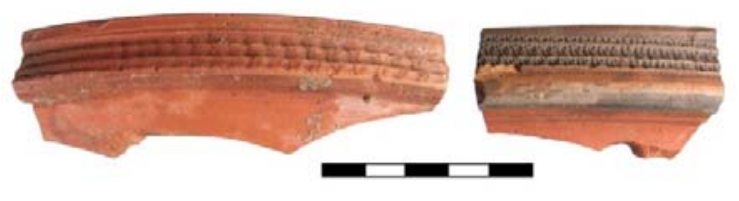

Figura 12. Amforă pontică (?) nedeterminată, Stânca Topalu 2006 (stânga).

Figura 13. Ceramică lucrată cu mâna și decorată cu impresiuni pe buză, Stânca Topalu 2006 (jos).

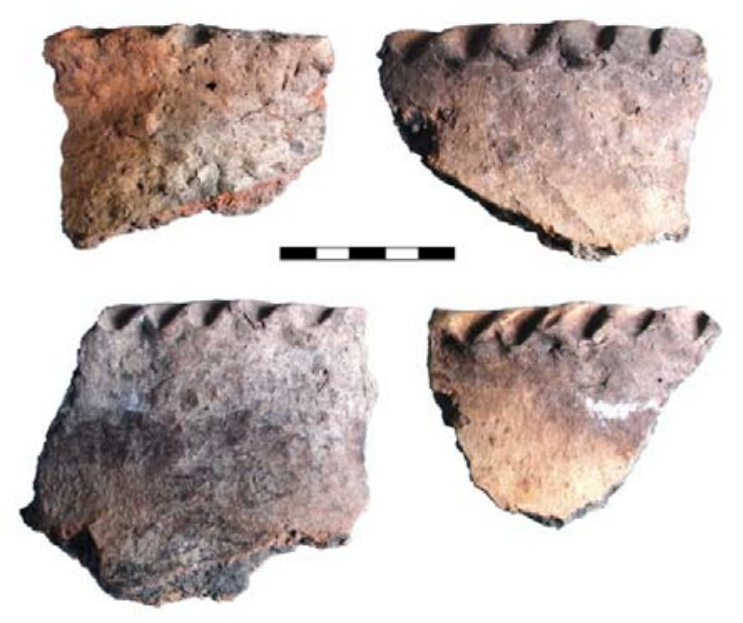

${ }^{27}$ Vezi Teodor 2010, 214, 218 pentru decorul de impresiuni cu degetul: '... rim decorated with fingerprints, a hallmark of the north-Pontic pottery...'. 


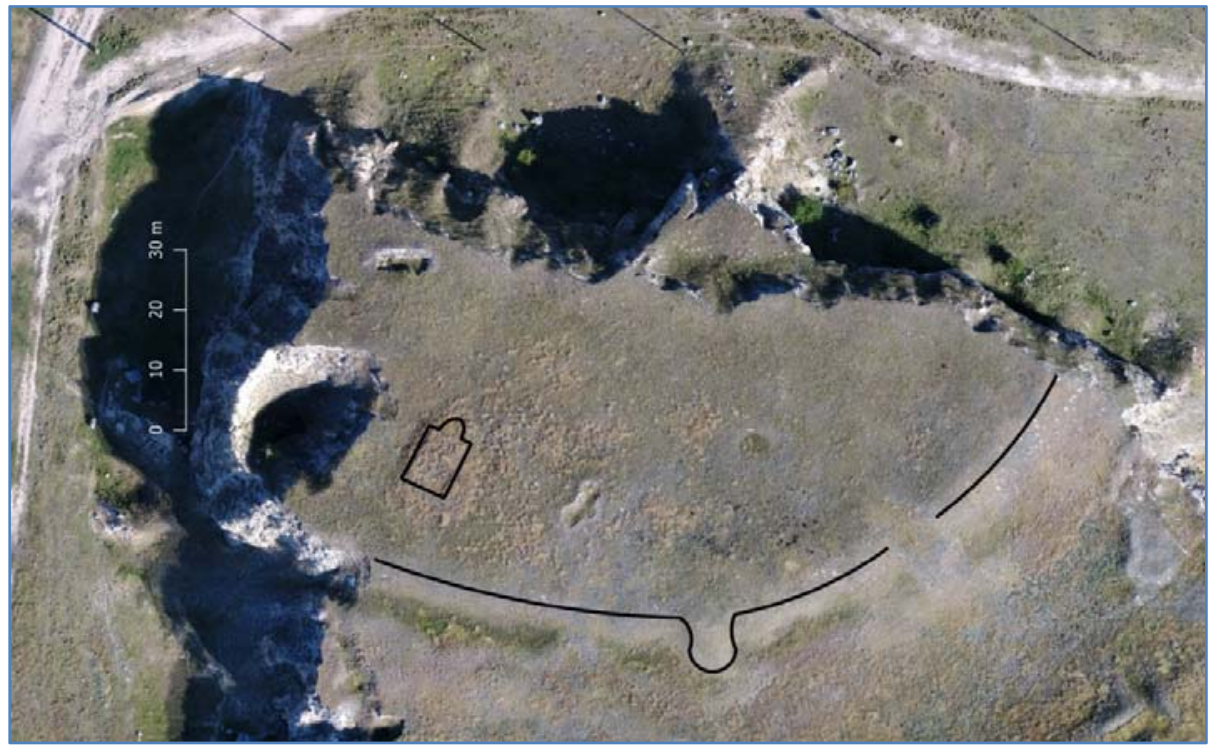

Figura 14.

Cetatea romană de la Stânca Topalu; de sus in jos: ortofotoplan, elevații, evidentierea pantelor (Dan Costea).

Sunt adăugate o formă basilicală și conturul probabil al fortificației. În partea nord-vestică se vede S.I/2006.
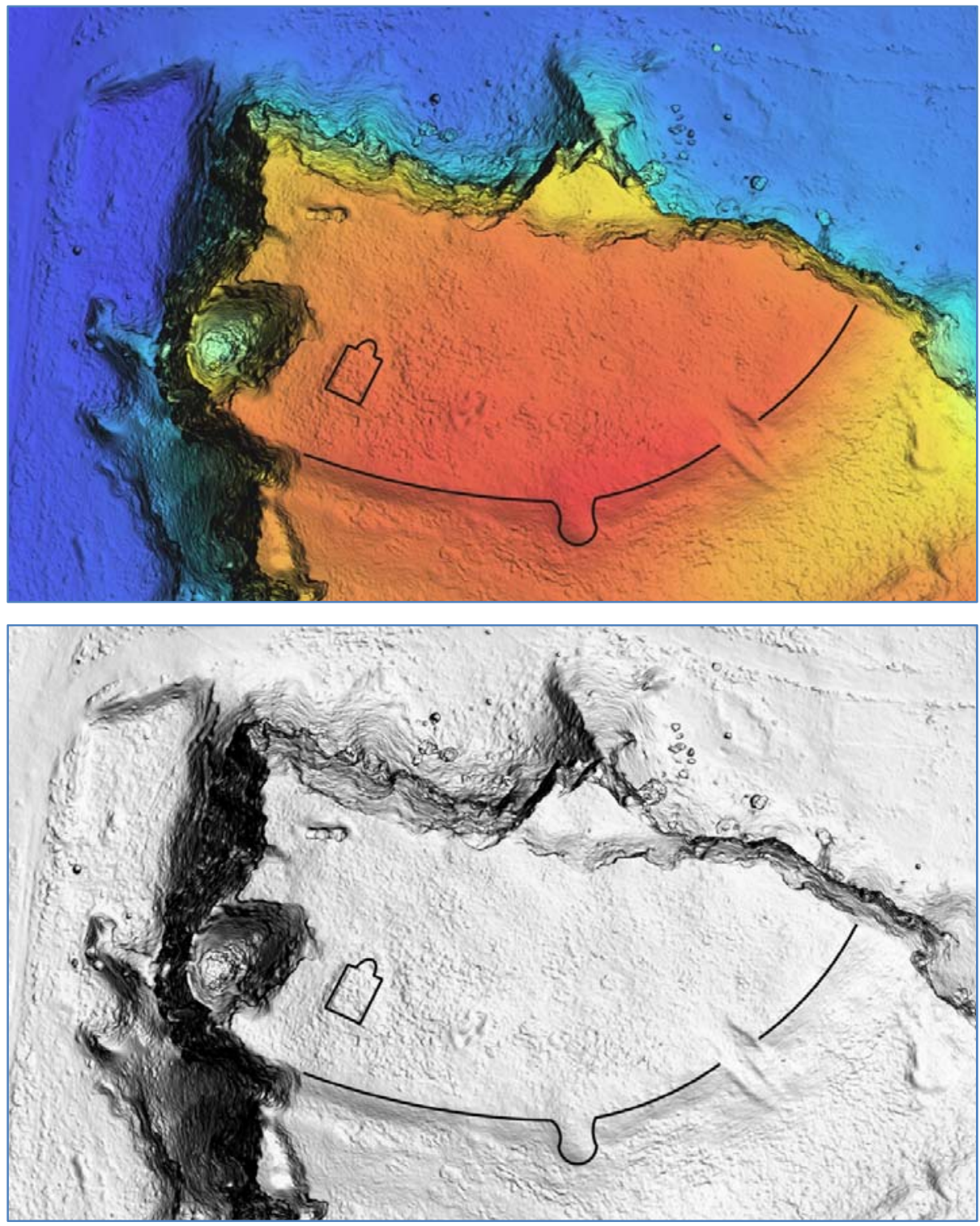


\section{CONCLUZII}

Materialul arheologic rezultat nu este nici foarte abundent sau expresiv, dar nici foarte clar legat, funcţie de cele trei unităţi stratigrafice cărora le aparţine, de complexe arheologice bine conturate. Rămân fără un răspuns pentru moment întrebările legate de datarea momentului de final al fortificaţiei şi poate cauzele părăsirii acesteia. În mod clar se impune deschiderea unei săpături arheologice sistematice și care, pe parcursul câtorva campanii să poată furniza așteptatele date asupra sistemului defensiv (incintă și val, deși mare parte din fortificaţie a fost deja iremediabil distrusă de cariera de piatră), cât şi asupra cronologiei relative a cetăţii romane târzii (şi poate romano-bizantine) de la Stânca Topalu. Un asemenea proiect ar putea foarte bine să aibă în vedere, bunăoară, cercetarea laturii de sud - incintă și val, vizibile pe fotografiile aeriene. Iar aceasta, cu atât mai mult cu cât noua documentare fotografică realizată în cadrul Programului Național Limes ${ }^{28}$ evidențiază nu doar sistemul defensiv, dar și un edificiu dotat cu absidă (biserică?) de cca 18 m lungime, cu absida orientată NNE-SSV, la mica distanţă de curtină, aproximativ la jumătatea laturii de sud (Figura 14). Aceasta va fi măsurat, potrivit lui Pamfil Polonic, 116 m, din care s-au mai păstrat cca $70 \mathrm{~m}$ liniari. În aceeași zonă de sud-est mai poate fi investigat un turn de colț, al cărui tip (circular sau în formă de evantai) este imposibil de precizat pentru moment, la fel cu o anomalie care poate reprezenta una dintre cele două porți văzute de Polonic cu mai bine de un secol în urmă.

$* * *$

Ioan C. Opriş (ioan_oprisATyahoo.com) este conferenţiar la Universitatea Bucureşti, Facultatea de Istorie.

Cătălin Dobrinescu (catalindobrinescuATyahoo.com) este arheolog la Muzeul de Istorie și Arheologie Constanța.

BIBLIOGRAFIE

ATLANTE I Enciclopedia dell'Arte Antica Classica e Orientale. Atlante delle forme ceramiche I. Ceramica fine romana nel bacino Mediterraneo (Medio e tardo Impero), Istituto della Enciclopedia Italiana, Roma, 1981.

Barnea 1991 Barnea, Alexandru, La Dobroudja aux $I V^{e}-V I I^{e}$ siècles n.è., în Suceveanu, Alexandru, Barnea, Alexandru, La Dobroudja romaine, Bucureşti, 1991, 154317.

Dima, Popescu 2005 Dima, Mihai, Popescu, Antoniu, Monede descoperite în Dobrogea, BSNR, 146$151,2005,367-374$.

Dobrinescu, Opriș $\quad$ Dobrinescu, Cătălin, Opriş, Ioan C., 194. Topalu, com. Topalu, jud. Constanţa. 2007 Punct: Stânca Topalu - Cekirgea, cariera Margela, în Cronica cercetărilor arheologice din România. Campania 2006, cIMec: Bucureşti, 382-383, 482 (=

\footnotetext{
${ }^{28}$ Fotografii aeriene și filmări cu drona realizate de Dan Costea, în cadrul Programului Național Limes, al cărui obiectiv este tocmai realizarea documentației pentru clasarea ca monument istoric și pentru monitorizarea strategiei de management a Limes-ului în vederea înscrierii pe Lista Indicativă a Patrimoniului Mondial - UNESCO a obiectivelor de patrimoniu cultural imobil ce au alcătuit frontiera Imperiului Roman pe teritoriul României (Muzeul Național de Istorie a României - responsabil pentru sectorul Sud-Est și Sud, corespunzător Carpaților Meridionali și sudului României). Mulțumim, totodată, domnului Vlad Călina pentru prelucrarea datelor fotografice recente obținute la cetatea de la Stânca Topalu.
} 
Florescu 1927-1932 Florescu, Gr., Fouilles et recherches archéologiques à Calachioi (Capidava?), Dacia, III-IV, 1927-1932, 483-515.

Gudea 2005

Gudea, Nicolae, Der untermoesische Donaulimes und die Verteidigung der moesischen Nord- und Westküste des Schwarzen Meeres: Limes et litus Moesiae Inferioris (86-275 n. Chr.), Jahrbuch des Römisch-Germanischen Zentralmuseums, 52, 319-566.

Hayes 1972

Hayes, J.W., Late Roman Pottery, The British School at Rome: London.

Munteanu 1975

Munteanu, Maria, Inscripții romane inedite din Scythia Minor, Pontica, VIII, 1975, 389-397.

Opriș 2003

Opriş, I.C., Ceramica romană târzie şi paleobizantină de la Capidava în contextul descoperirilor de la Dunărea de Jos (sec. IV-VI p.Chr.), Editura Enciclopedică: Bucureşti.

Opriș 2014

Opriș, Ioan, Starea arheologiei dobrogene în primele două decenii ale secolului al XX-lea. Începuturile muzeografiei constănțene/ The status of the archaeology in Dobrudja in the first two decades of the 20th century. The beginnings of museography in Constanța, în A.D. Stănică, C.L. Micu (ed.), Studies and Papers on Dobrudjan History. Istro-Pontica National Scientific Session "Tulcea -505 years since the first documented mention", Tulcea, 2011, September 28th-30th, Istro-Pontica, 2, Ed. Istros: Brăila, 199-220.

Opriș 2018a

Opriș, Ioan C., Inceputurile cercetării arheologice la Capidava. Documente inedite/ The beginnings of archaeological research at Capidava. Unpublished documents, Pontica, LI, 2018, 59-80.

Opriș $2018 b$

Opriş, Ioan C., Aurélien en trois fois. Bornes milliaires à Capidava et dans le territorium Capidavense, în LA DACIE ET L'EMPIRE ROMAIN. Mélanges d'épigraphie et d'archéologie offerts à Constantin C. Petolescu, M. Popescu, I. Achim, F. Matei-Popescu (éds.), Editura Academiei, Bucarest, 2018, 159-172.

Opriș, Ștefan, Duțescu 2008

Opriş, Ioan C., Ştefan, Dan, Duţescu, Maria Magdalena, Territorium Capidavense - cercetări de suprafatăa în Cronica cercetărilor arheologice din România. Campania 2007, cIMec, 2008, 87-89, pl. 19.

Paraschiv 2006

Paraschiv, D., Amfore romane și romano-bizantine în zona Dunării de Jos (sec. I-VII p.Chr.), Iași, 2006.

Pârvan 1914

Pârvan, Vasile, Archäologische Funde im Jahre 1913. Rumänien, Archäologischer Anzeiger, Jahrbuch des Kaiserlich Deutschen Archäologischen Instituts, XXIX, 1914, Berlin, col. 429-442.

Polonic 1935

Polonic, Pamfil, Cetățile antice de pe malul drept al Dunării (Dobrogea) până la gurile ei, Natura. Revistă pentru răspândirea științei, XXIV, 7, (15 iulie) 1935, 18-26.

Teodorescu 1915 Teodorescu, D.M., Monumente inedite din Tomi, Buletinul Comisiunii Monumentelor Istorice, VIII, 29/1, 1915, 6-20.

Teodor 2010

Teodor, Eugen S., Handmade pottery from the Late Roman Fortress at Capidava, în A. Măgureanu, Erwin Gáll (ed.), Intre stepă și Imperiu. Zwischen der Steppe und dem Reich/ Between the Steppe and the Empire, Studii in onoarea lui Radu Harhoiu. Archäologische Studien für Radu Harhoiu zum 65. Geburtstag/ Archeological Studies in honour of Radu Harhoiu at $65^{\text {th }}$ Anniversary, Renaissance: Bucureşti, 2010, 211-223.

Topoleanu, Teodor Topoleanu, Florin, Teodor, Eugen S., Hand-made Pottery from Halmyris and its 2009 Cultural Context, Peuce VII, 2009, 347-360. 
Zahariade, Gudea 1997

RIC VIII

TIR L 35
Zahariade, Mihail, Gudea, Nicolae, The fortifications of Lower Moesia (AD 86275), Adolf M. Hakkert Publisher, Amsterdam, 1997

Roman Imperial Coinage, Volume VIII = Carson, R., Sutherland, H., Kent, J., The Roman Imperial Coinage, Vol. VIII, The Family of Constantine I, A.D. 337 -364, London, 1981.

Gostar, N., Daicoviciu, C., Condurachi, E., Tabula Imperii Romani (RomulaDurostorum-Tomis), sur la base de la Carte internationale du monde à l'échelle de 1:1000000. L 35, Bucarest, 1969.

\section{ILLUSTRATIONS}

Figure 1. Stânca Topalu, Ortophotoplan ANCPI, 2012, with the positioning of the former stone quarry and the fort.

Figure 2. The Szatmári Map, detail of Scârția Valley and of the Atârnați Island, the place of the fort being marked with an arrow.

Figure 3. The Artillery Directory Plan, no. 5346/1928, Muslu Bei, detail of the Cekirgea Valley and the Minaveli Quarry. Kilometric Grid.

Figure 4. The plan of the fort from Stânca Topalu - Pamfil Polonic, Mss. The Romanian Academy - The Cabinet of Manuscripts and Rare Books, no. 189/12. Orientation approx. N-V.

Figure 5. Relief discovered at Stânca Topalu. Procesed photograph after Teodorescu 1915, 15-16, no. 37. Figure 6. Roman brick construction at the base of the Stânca Topalu Hill- 1913 (after Pârvan 1914, col. 431, Abb. 2).

Figure 7. Stânca Topalu, site sketch with the location of SI / 2006.

Figure 8. Stânca Topalu, section SI / 2006, southern profile and plan.

Figure 9. Stânca Topalu, section SI / 2006, westward view.

Figure 10. Stânca Topalu, section SI / 2006. Brick and stone rubbles in situ.

Figure 11. Late Roman C / Phocean Ware, three bowl fragments.

Figure 12. Atypical Pontic amphora (?), Stânca Topalu 2006.

Figure 13. Hand-made pottery, finger-pressed decorations along the rim, Stânca Topalu, 2006.

Figure 14. The Roman fort from Stânca Topalu; top to bottom: orthophotoplan, elevations, slope highlighting (Dan Costea). Also added a basilica shape and the probable outline of the fortification. In the northwest one can see S I / 2006. 
ANEXA I

Pamfil Polonic, Cercetările de la Hârşova până la Ostrov (Silistra), Cabinetul de Manuscrise și Carte Rară - Mss. Academia Română, p. 4-5.

Cetatea romană de la Cekirgea (Cariera Margela)

La 4 km spre nord de comuna Topalu/ găsim pe malul stâng al vaei/ Cekirgea lângă Dunăre o cetate mare romană de peatră. - Ea are în/ total forma patrată, iese însă în colţul de nord/ vest puţin afara (cu $40 \mathrm{~m}$ ) acomodândusel formei terenului. Laturele ei despre nord/ şi vest se reazămă pe malurile abrupte şi/ stâncoase a platoului, sub care astăzi funcţionează o carieră (numită Margela)/ de unde se scoate peatră pentru fabrica/ de cement a inginerului Cantacuzino din Brăila. Cetatea este înconjurată în partea despre est/şi sud cu un val de $10 \mathrm{~m}$ lat şi $1 \mathrm{~m}$ inalt/ pe care se văd urmele unui zid de peatră/ care arată o grosime de $2 \mathrm{~m}$, / şi un şant de apărare de 2-3 $\mathrm{m}$ adânc/

\section{şi 20-30 m lat./}

Latura despre sud măsoară 116 m, cea despre/ răsărit 140 m în cea din urmă găsim urmele a două/ intrări und cred că au fost porţile cetăţei./ Latura despre nord are o lungime de $64 \mathrm{~m}$ care însă se prelungeşte cotind pe o lungime de $40 \mathrm{~m}$ drept spre nord/ acomodânduse astfel formei terenului. Latura despre/ apus are o lungime de $170 \mathrm{~m}$ şi se reazămă/ pe malul abrupt al Dunărei./

In interiorul cetăţei se văd urme de construcţiuni/ de case. Cetatea este acum încă bine conservată/ dar dacă nu se va opri exploatarea carierei/ ea va fi cu timpul cu totul distrusă.

Aici s-au găsit de cătră/lucrătorii italieni care şiau/construit în vale locuinţe solide monede/ romane şi bizantine.

\section{ANEXA II - ARHIVA MNA}

1. Scrisoare Gr. Florescu către Prof. Ioan Andrieșescu, directorul MNA - 3 august 1927 MNA Fond 1927, datat August 9 1927, nr. 57

Calachioi, 3 August 1927

Domnule Director

Conform delegației ce mi-aţi dat înainte de a pleca la Calachioi pentru continuarea săpăturilor arheologice, astăzi de dimineață plecai cu o căruță la cariera Dlui Cantacuzino din apropierea comunei Topalu spre a vedea în ce stare se mai găsește cetatea așezată deasupra masivului în exploatare. Știam că acest monument istoric - care avea să ne aducă încă o faclă luminoasă în întunericul trecutului nostru și deci o pârghie mai mult la întărirea conștiinței românești în viitorul plin de nădejdi - deși scăpat destul de teafăr, față de altele, de urgia barbarilor năvălitori prin aceste locuri înfloritoare de civilizație romană, a fost totuși dăruit de generozitatea autorităților noastre superioare, cu toate intervențiile protivnice ale mult regretatului director al Muzeului Naț. de Antichităţi, V. Pârvan, barbarei exploatări a numitului mai sus domn. $\mathrm{Cu}$ toate acestea, cu un fel de durere umilitoare în suflet, voiam ca măcar obiectele, ce ar ieși la iveală din dărâmarea edificiilor în timpul exploatărei, să nu se prăpădească, fiind transformate în ciment, ci să fie alese prin o mică bunăvoință din partea personalului administrativ al carierei și încredinţate 
Muzeului Naț. de Antichități spre a fi studiate și păstrate. $\mathrm{Cu}$ aceste intenții ajungând la carieră/m'am adresat d-lui Matușefschi, administratorul carierei, întrebându-l dacă nu s'a găsit ceva - piatră scrisă, sculptată sau vreun alt obiect - în dărâmăturile cetăței. Mi-a răspuns, întorcându-mi spatele, că nu se ocupă el de „fleacuri”. Nevoind însă să plec fără un rezultat precis, întru cât aveam informații că obiecte au fost găsite, m'am adresat a doua oară căutând să îl conving că eu mă interesez de aceste lucruri fiind obligat de legile țărei după cum și el este obligat de aceleași legi de a respecta aceste monumente. La acestea mi-a răspuns că ,dacă nu părăsesc cariera mă scoate legat afar(ă)”, apoi, ca o justificare a procedeului său [...] îmi spune că ,acum Pârvan a murit și dacă el n'a putut face nimic ca să opriască cariera noi ce mai vrem?" Suportând toate acestea, spre a putea avea o cât de mică lămurire asupra informațiilor căpătate din altă parte privitoare la găsirea de obiecte în dărâmăturile cetăței, repet din nou întrebarea respectivă. Din nou însă domnul Matușefschi se întărâtă și după ce îmi spune "să părăsesc cetatea că mă ia la palme" adresându-mi în același timp un torent de înjurături grosolane, ca să termine, declară în sfârșit că ceea ce a găsit a trimes la Constanța, la Iași și la București. Tot astăzi aflu în satul Topalu că în vara aceasta au fost acolo doi domni de la Iași cari au ridicat mai multe obiecte găsite în dărâmăturile cetăței.

Așa dar cetatea romană așezată deasupra carierei D-lui Cantacuzino continuă a fi dărâmată de către stăpânul carierei cu aceeaș vrednicie cu care își exploatează cariera; obiectele ce se găsesc în dărâmăturile cetăței se distribuie după bunul plac/ al administratorului carierei, iar persoanele cari servesc instituția însărcinată cu ocrotirea și punerea în valoare științifică a acestor monumente, când se prezintă ca să-și facă datoria impusă, sunt insultate în mod grosolan și amenințate cu bătaia. Aceasta este situația reală a străduințelor noastre, desigur, creată și favorizată de autoritățile noastre superioare.

Primiți vă rog D-le Director încredințarea deosebitei mele stime.

Grigore Florescu

Asistent universitar

D(omniei) Sale

Dlui Director al Muzeului Naţional de Antichități

La această scrisoare Ioan Andrieșescu pune următoarea rezoluție:

„Se va comunica urgent cazul Comis. Mon. Istorice și Ministerului de Interne, cu rugămintea de a lua măsuri. Ministerul de Interne prin organele sale să puie în vedere exploatatorilor că se expun pentru călcare de lege și în plus se expun la dare în judecată pentru ultraj în exercitarea funcțiunei trimișilor noștri. IA"

„Urgent. 1. Către Com.Mon.Ist. 2. Către Ministerul de Interne. 3. Telegramă d-lui Florescu că s-au avizat autoritățile cerându-se insistent măsuri energice". 


\section{Copie Nr. 59/ 1927}

D-sale Domnului Președinte al Comisiunii Monumentelor Istorice

Domnule Președinte,

Dl Grigore Florescu, profesor secundar și asistent la Universitate, având misiunea de a continua săpăturile archeologice dela Capidava (căt. Calachioi, jud. Constanța) și de a executa explorări sumare la cetatea romană imediat vecină, situată lângă com. Topalu, ne raportează cu data de 3 August a.c. că mergând în această din urmă localitate, a constatat că cetatea e pe cale să fie distrusă fără veste de exploatatorii cari, sub firma Cantacuzino, au în concesie sau în arendă dela Stat cariera de piatră din partea locului.

Delegatul nostru cu legitimare întărită și de Comisiunea M(onumentelor) I(storice) nici nu a putut măcar încerca să se informeze despre cele văzute: administratorul carierei Cantacuzino, un domn Matușevschi, după ce a proferat înjurături grosolane 1-a amenințat „,că dacă nu pleacă imediat, îl scoate legat și bătut”; că de obiectele găsite dispune el, administratorul, dându-le cui vrea prin orașele Constanța, Iași și București.

Această nemai pomenită împrejurare ne desvăluie o stare de lucruri cel puțin îngrijorătoare:

1. $\quad$ Faptul că la Topalu - după datele noastre precise de la dosar - s'a exploatat și se exploatează de către particulari o suprafață totală de 91 (nouăzeci și unu) hectare cariere de piatră, concesionate sau arendate de Stat, dar nu a putut fi cruțată cetatea romană (avea un hectar și jumătate);

2. Faptul că autoritățile în subordine ale Statului (administrația plășii, anume secția de jandarmi) s'au simțit emoționate de autoritatea exploatatorilor carierei de piatră, lăsând să fie călcate dispoziţiunile legii pentru descoperirea și conservarea monumentelor istorice;

3. Faptul, deopotrivă de grav, că un funcționar al Statului, delegat oficial să îndeplinească o misiune științifică și administrativă - una din cele mai trudnice -a putut fi ultragiat fără o urmare imediată, de un personagiu prepus al unei firme particulare de comerț.

Pe baza celor expuse până aci avem onoarea a Vă ruga să binevoiți a interveni pe lângă Onor Min. de Industrie și Comerț, ca cel puțin acum, cât nu e încă prea târziu, administrația carierii să fie determinată energic, potrivit legii, să oprească de urgență sălbatica devastare a cetății; de asemenea, pe lângă Onor Min. de Interne, spre a se ancheta la faţa locului, iarăși potrivit legii, în unire cu delegatul nostru, devastările pricinuite și către cine din orașele Constanța, Iași și București au fost înstreinate obiectele găsite.

Director,

Prof. Ioan Andrieșescu

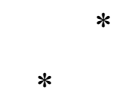

\section{Copie Nr. 68/ 1927 August ...}

D-sale Domnului Ministru de Interne

Domnule Ministru,

Pe malul Dunării lângă com. Topalu din jud. Constanța se află o veche cetate romană, cu a cărei cercetare și explorare preliminarii este însărcinat delegatul nostru dl Gr. Florescu, asistent universitar și profesor de liceu. Cele constatate de Dsa acolo în ziua de 3 august a.c. și comunicate nouă prin rap. său din aceeași zi, constituie o dureroasă și neașteptată surprindere. 
Administrația - arendașe din carierele de piatră - ce însumează în jurul com. Topalu o suprafață totală de 91 ha - și anume firma Cantacuzino, prin administratorul său, un domn Matușevski, a găsit mijlocul expeditiv și practic de a extrage piatră lucrată gata: din însăși cetatea romană, desființând fără urmă ziduri întregi și înstrăinând monumentele, ce se găsesc totdeauna din abundență într'o cetate antică. Constatăm, deci, pe de o parte, o exploatare particulară, abuzivă și distrugătoare de nenumărate și neprețuite documente valoroase pentru istoricul acestei cetăți antice, ca și pentru cadrul general al istoriei Dobrogei romane; pe de altă parte lipsa totală de inițiativă și împotrivire, precum și tăcerea a(supra) faptelor din partea autorităților comunale locale.

Asupra soluționării cât mai grabnic a acestor fapte - pe care, cu raport deosebit, le-am adus la cunoștința Onor. Comisiunii Mon. Istorice -, avem ononare a Vă ruga, D(omnule) M(inistru), să binevoiți a ne acorda înaltul Dvoastră sprijin, binevoind a dispune să se oprească de urgență exploatarea și să se instituie o anchetă la fața locului - cu privire la acțiunea de devastare a numitei administrații de cariere de piatră și de a se ordona autorităților din comuna Topalu stricta aplicare a legii pentru descoperirea și conservarea monumentelor istorice.

Director,

Prof. Ioan Andrieșescu

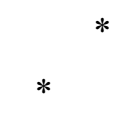

4. București, 21 septembrie 1927, nr. 994; nr. 88/1927

Domniei-Sale Domnului Director al Muzeului Național de Antichități. Loco

Ministerul Cultelor și Artelor

Comisiunea Monumentelor Istorice

Domnule Director,

În referire la adresa Dvoastre No. 59/din 11 august a.c. și a intervenţii Comisiunii Monumentelor Istorice cu adresele No 945 către Ministerele de Industrie și Interne avem onoare a vă înainta în copie răspunsul Ministerului de Industrie cu No. 68010 din 6 Sept. a.c. asupra măsurilor ce s'au luat contra devastării cetății vechi romane de la Topalu, jud. Constanța.

Pentru Președinte

Gh. Balș
Secretar-Director

V.N. Drăghiceanu

5. Copie după Adresa Ministerului de Industrie No. 68010 din 6 Sept. a.c.

Anexă la CMI 994/1927

Domnule Ministru,

Referindu-ne la întâmpinarea Dv. No. 945/1927 înreg. la No. 79509/927, avem onoare a vă aduce la cunoștință că am dat cuvenitele dispozițiuni Subinspectoratului Minier Buzău, spre a înpiedeca extragerea 
de materiale din vechea cetate romană de la Topalu, instituind în acelaș timp și o zonă de protecție în conformitate cu prescripțiunile art. 70 din Legea Minelor.

Ministru, ss. indescifrabil
Director General

(ss - ) Zamfirescu

\section{Ministerul de Interne}

Direcțiunea Administrației Generale, Contenciosului și Statisticii

No. 29795 A. 17 NOE 1927

Domnului Ministru al Cultelor și Artelor

Direcțiunea Muzeului de antichități - Bulevardul Academiei No 7 (Universitate)

Domnule Ministru,

Avem onoare a răspunde adresei D-vs No. 68 din 12 August a.c., că, din cercetarea făcută atât de D-1 pretor al plășei Hârșova, cât și de D-1 prefect al județului Constanța, personal, în ziua de 12 Octombrie 1927, rezultă că pe tot perimetrul concesiunii carierelor de piatră din Topal nu se găsește nici o cetate romană, sau vre-un monument istoric.

În cariera Topal se găsește numai o urmă de zid vechiu, care este respectat de firma Ion C. Cantacuzino, prin delegatul său D-1 Emil Matușefschi.

Cariera se exploatează în aer liber și, deci, dacă s'ar afla vre-un monument, sau cetate istorică, s'ar vedea imediat.

Firma I. Cantacuzino, prin delegatul său, și-a luat angajamentul ca, în cazul când în cursul exploatărei se va descoperi ceva de interes arheologic istoric, sau preistoric, să comu-/nice telegrafic D-lui Prefect, spre a lua măsurile de rigoare.

p. Ministru, ss. indescifrabil
Director General

ss. indescifrabil

\section{Ministerul Cultelor şi Artelor}

Comisiunea Monumentelor Istorice

București, 25 Noembr. 1927 No. 1253/ MNA No 109/1927

Cu nota directorului MNA Ioan Andrieșescu: „26.XI.1927. după ce se va înregistra dl Grigore Florescu este rugat să facă urgent un referat detaliat și precis. I.A."

Domnule Director, 
Avem onoare a vă înainta în original adresa Ministerului Industriei și Comerțului No. 88843/1253/ a.c. rugându-vă să binevoiți a cerceta și a ne comunica care e situația pietrelor extrase din vechea cetate romană Topalu.

Pentru Președinte

Gh. Balș
Secretar-Director

V.N. Drăghiceanu

\section{Ministerul Industriei și Comerțului \\ Direcțiunea Generală a Minelor}

No 88843 din 17 Noe. 1927/ Ministerul Artelor și Cultelor No 01253 / 18 Noe. 1927

Comisiunii Monumentelor Istorice

Ministerul Cultelor și Artelor

În referire la adresa Dvs. Nr. 945, avem onoare a vă aduce la cunoștință că am luat măsurile cuvenite ca, în conformitate cu prescripțiunile art. 70 din legea minelor, să fie împiedecată extragerea de materiale din vechea cetate romană dela Topalu, instituindu-se o zonă de protecție de $20 \mathrm{~m}$.

Totdeodată vă facem cunoscut că autoritatea minieră regională ne-a raportat că Direcțiunea Muzeului de antichități vinde piatra extrasă dela descoperirea cetății.

Deoarece legea minelor promulgată cu Înaltul Decret Regal Nr. 2294 din 3 Iulie 1924 și publicată în Monitorul Oficial Nr. 143 din 4 Iulie 1924, arată clar că numai Ministerul Industriei și Comerțului este în drept să dispună de carierele statului și de materialele ce se află depozi-/tate pe suprafața acestor cariere, vă rugăm a lua măsuri ca organele Dvs. din comuna Topalu să nu vânză piatra extrasă de la descoperirea cetății romane, despre care tratează susmenționata Dvs. adresă cu Nr. 945/ 30 August 1927.

Pentru Ministru ss. indescifrabil
Director General

ss. indescifrabil

9. Notă internă - H. Metaxa

Referat (la no 109 și 108 dosar 1927)

Nu e de prisos să relevez în chestiunea Topalu (dosar 1927/ nr. 57, 59, 68) contradicțiile dintre cele două adrese.

1. În privința stării de fapt: adresa Min. de Industrie cu nr. 88843/ 1927 constată „,vechea cetate romană de la Topalu" și restituie o foarte utilă zonă de protecție de $20 \mathrm{~m}$;

Adresa Min. de Interne cu nr. 29795 A/1927 găsește „numai o urmă de zid vechiu” pe toată întinderea perimetrului carierelor de piatră.

2. Iar în privința consecinții existenței minelor: Min. de Industrie (88843/ 1927) este informat că Muzeul Naţional ,vinde piatra extrasă de la descoperirea cetății” (Topalu);

Min. de Interne încuviințează că firma exploatatoare, prin delegatul său, dl. Emil Matușefschi, respectă „urma de zid vechiu”. „Dacă s'ar afla vreun monument sau cetate istorică, s'ar vedea imediat”./ 
Iată deci cât e de patent că cele două autorități superioare au fost informate eronat de către autoritățile locale în subordine, - în deosebi reprezentantul regiunii miniere, care va trebui obligat sub o formă sau alta să și dovedească grava afirmație ce înaintează și, în parte, Dl Pretor al plășii Hârșova, insuficient informat.

Protestele pe care direcțiunea Muzeului le-a făcut ani de-a rândul, în scris și verbal, cerând să se păstreze rămășițele istorice, s'au izbit de obiceiu (acolo unde Muzeul nu putea să aibă gardieni bugetari proprii) de reaua voință a autorităților celor mici, locale.

Dovada se poate găsi în comunicarea „Descoperiri nouă în Scythia Minor” (1913) de V. Pârvan:

1. Distrugeri din cauza unei „cariere de piatră” la Capidava (Calachioi), -pag. 9;

2. Distrugeri vechi, făcute și de orășeni însă, la Carsium (Hârșova), -pag. 12;

3. Distrugeri la Troesmis (Iglița-Turcoaia), p. 26/ și distrugeri la Sucidava (jud. Rom.), p. 26, nota 1.

La Topalu însă, - stațiune antică neidentificată, până astăzi și neidentificată vreodată, dacă se va adeveri că din ea nu mai subzistă decât „o urmă de zid vechiu” - , vechimea și continuitatea exploatării acestei cariere de piatră se poate documenta printr'o altă lucrare, de astă dată în 1. germană a regretatului nostru director V. Pârvan. Într-un Bericht (1914), pag. 430-431, spune: "... wurden bei Topalu... die Fundamente eines mächtigen römischen Ziegelbaues (Abb. 2) und zwei parallele ... Kanäle aufgedeckt, die aber von den Stellvertretern des Terraineigentümers fast vollständig demoliert worden waren... zum römischen Kastell und vicus von Topalu gehören ... noch jetzt, trotz aller Proteste ... als Steinbruch dienen”. Fig. 2 înfățișează o săpătură respectabilă, de lungă durată.

Obiecte, cum e și firesc, s-au găsit întotdeauna la Topalu - și în privința aceasta știm care e adevărul, din replica plină de sfidare a Dlui Matușefschi adresată dlui Grig. Florescu, acum câtva timp. La pag. 430 din amin-/ titul Bericht, citim: "Erwähnt seien: ein Relief des thrakischen Reiters, gefunden in den Ruinen des römischen Lagers bei Topalu, ... jetzt in der Constantzaer Zweiganstalt des Nationalmuseums für Altertümer"...

Este cel publicat de D1 D.M. Teodorescu în „Monumente inedite din Tomi” (1915) p. 85-87, nr. 37, fig. 44. Este, în acelaș timp, unicul monument care, după câte țin minte, n'a fost inventariat drept piatră de var, în decursul îndelungatei exploatări ce a suferit această stațiune din partea firmei I. Cantacuzino.

28.XI.1927

(H.M. - n.n. Harilaos Metaxa)

Gr. Florescu către Directorul MNA

Dintre cele două adrese înmânate mie spre a referi una (a onor. Minister al Ind. şi Comerțului no 88843/17 Noembr. 1927) recunoaște existența cetăței antice de la Topalu pe locul carierei Firmei I. Cantacuzino și afirmă instituirea unei zone de protecție de $20 \mathrm{~m}$, cealaltă (a onor. Minister de Interne No 29725) spune că „pe tot perimetrul concesiunii carierelor de piatră din Topalu nu se găsește nicio cetate romană sau vreun monument istoric”, afară de „numai o urmă de zid vechiu” aflător în cariera Topalu.

Deci o contradicție flagrantă între constatările a două dintre organele autorităților superioare ceeace însemnează că ancheta ordonată nu e făcută în chip serios. Și de fapt nu putem avea pretenție la seriozitatea acestei anchete întrucât cei care au făcut-o nu aveau de loc pregătirea spre a face constatări ce țin de domeniul archeologiei. Se impune așa dar o nouă anchetă care să se facă de o comisie în care unul dintre membrii ei să fie specialist în archeologie. 
În partea ei finală adresa onor Ministerului Industriei afirmă că eu aş fi vândut piatră extrasă din descoperirea cetăței de deasupra carierei în chestiune și deci aș fi contravenit Legei Minelor publicată în Mon. Oficial No 143 din 4 Iulie 1924 care ,,arată clar că numai Ministerul Industriei și Comerțului este în drept ca să dispună de carierele statului și de materialele ce se află depozitate pe suprafața acestor cariere". O afirmație pe cât de mincinoasă pe atât de doveditoare că ancheta s'a făcut în chip neserios. Căci după cum v'am raportat în August a.c. eu am fost calomniat și a fost cât pe aci să fiu bătut de administratorul carierei Cantacuzino numai pentru faptul că am intrat în carieră și am voit să mă interesez de obiectele ce ar mai fi ieșit din dărâmarea cetăței deci cum ași fi putut descoperi cetatea și să și vând chiar material rezultat din descoperire./

Se vede de aci totuși că delegatul Min. Industriei însărcinat cu ancheta a cules informații în grabă și fără niciun control. Că eu din 1924 lucrez la descoperirea unei cetăți e adevărat și după cum știți această cetate e Capidava situată în marginea satului Calachioi. Și teritoriul acestei cetăţi, în urma exproprierei, e trecut în proprietatea Muzeului Național de Antichități, deci Ministerul Industriei n'are niciun amestec aci. Când am început săpăturile aci neavând material rulant ca să transport pământul și molozul amestecat cu bucăţi de piatră brută scoase din tranșeele făcute pe lângă zidul înconjurător al cetăței, le-am aruncat într'o parte a acestor tranșee. După ce am terminat liberarea acestui zid, regretatul director al Muz. N. de Ant. V. Pârvan venind în inspecție și entuziasmat de buna stare de conservare a cetăței cum și de forma ei regulată a luat hotărârea ca această cetate să fie complet săpată și consolidată spre a rămâne ca monument istoric model. În consecință mi-a dat ordin să curăț complet dărâmăturile de pe lângă zid ca acesta să rămână în întregime vizibil. Spre a nu cheltui însă din fondurile date de Min. Cultelor, care voiam să-mi aducă noi rezultate științifice, cu o lucrare al cărui scop era mai mult de înfrumusețare am recurs la locuitorii satului. Anume le-am dat voie ca din pământul și molozul pe care eu îl aruncasem din săparea tranșeelor pe lângă zid să aleagă și să ia ei piatra - de care aveau nevoie pentru repararea gardurilor etc. distruse în timpul răsboiului - în schimb să curețe tot locul de jur împrejurul cetăței de tot pământul și molozul ce va rămânea. Această măsură a mea a fost aprobată și de fostul Director al Muz. V. Pârvan. Timp de doi ani însă am întrerupt săpăturile și când le-am reluat în vara anului 1926 n'am mai găsit aceeași bunăvoință la locuitori pentru că mulți dintre ei își luaseră piatra de care aveau nevoie pe furiș cu toată supravegherea gardianului pe care-1 lăsasem și pe care atunci când îi prindea îl amenințau cu bătaia. S'au prezentat numai doi inși, aceștia însă nu se obligau să curețe locul ci piatra pe care aveau s'o ia ei s'o plătească. Am admis acest/ lucru întrucât cu banii încasați putem pune lucrători cu plată să-mi facă munca respectivă. Totodată am dat ordin gardianului ca dacă se va începe construcția șoselei care trece pe lângă cetate înspre Topalu să vorbească ca pickerul să ia piatra și molozul scos de mine din săpături fiind săpat gata și la îndemână și să-l întrebuințeze la construcția acestei șoseli. Deci acest material este tot ceea ce se aruncă din desgroparea cetăței iar măsura luată de mine nu contravine niciunei legi ba mai mult dacă va fi realizată complet va produce rezultate satisfăcătoare pentru toată lumea. Dacă totuși Onor. Minister al Industriei are pretenții asupra acestui material eu îl dăruesc cu cea mai mare bucurie și îmi voi arăta toată recunoștința mea, dar numai în condițiile de mai sus și fără întârziere.

\section{Gr. Florescu}


11. Copie

No $112 / 8$ dec. 1927

Către Președintele Comisiunii Monumentelor Istorice / Dir. MNA Ioan Andrieșescu

Domnule Președinte,

La no. 1253, prin care suntem întrebați asupra pietrelor extrase din vechea cetate de la Topalu, aceasta în referire și la adresa Ministerului de Industrie și Comerț - Direcția Minelor, îndreptată către Dvoastră și prin care vi se face cunoscut că ,autoritatea minieră a raportat Ministerului (de Industrie și Comerț) că Direcțiunea Muz. Național de Antichități vinde peatră extrasă de la descoperirea cetății (sic)”, avem onoarea a vă comunica următoarele:

Adresa Ministerului de Industrie și Comerț se bazează pe informație cu totul insuficientă și inexactă.

În prima parte a acesteia se zice că ,în referire la adresa no. 945” (adresată D-voastră) „vă aducem la cunoștință că am luat măsurile cuvenite ca, în conformitate cu prescripțiunile art. 70 din Legea Minelor, să fie împiedicată extragerea de materiale din vechea cetate romană de la Topalu, instituindu-se o zonă de protecție de 20 m”. Iar mai departe: „Tot odată vă facem cunoscut că autoritatea minieră regională ne-a raportat, că Direcțiunea Muzeului de Antichități/ vinde piatra extrasă de la descoperirea cetății”. Astfel scrie adresa Minist. Industrie și Comerț - Direcția Minelor.

Iată însă că tot în aceiași vreme, primim direct din partea Ministerului de Interne adresa No. 29795 A prin care, la o plângere a noastră că Firma I. C. Cantacuzino și anume delegatul ei la carierele de la Topalu a violentat în August trecut pe delegatul nostru, care avea misiunea să vadă cum se face exploatarea carierii și cum se respectă Cetatea sau urmele ei -, Ministerul de interne ne răspunde că din cercetarea făcută rezultă „că pe tot perimetrul concesiunii carierelor de peatră din Topalu nu se găsește nici o cetate romană, sau vre-un monument istoric”. Și mai departe: „În cariera Topal se găsește numai o urmă de zid vechiu, care este respectat de către Firma I.C. Cantacuzino, prin delegatul său d. Emil Matușefschi”. „Cariera se exploatează în aer liber și, deci, dacă s'ar afla vre-un monument, sau cetate istorică, s'ar vedea imediat”. „Firma, prin delegatul său, și-a luat angajamentul ca în cazul când în cursul exploatării s'ar descoperi ceva, să comunice telegrafic D-lui Prefect” etc.

Contradicția dintre cele două adrese este evidentă și multiplă.

În timp ce Ministerul de Industrie și Comerț făgăduiește să aplice legea și să împiedice extragerea de materiale din „vechea cetate de la Topalu” - ba chiar să instituie o zonă de protecție -, Ministerul de Interne insuficient informat tăgăduiește aproape existența unei cetăți și o reduce la „o urmă de zid vechiu", ceia ce nu corespunde de loc cu adevărul.

Tot așa, în timp ce autoritatea minieră regională raportează că Direcțiunea Muzeului de Antichități vinde peatră extrasă de la ,descoperirea cetății,, -, Ministerul de Interne este informat de organele sale cu totul altfel: „Cariera se exploatează (de firma I.C. Cantacuzino) în aer liber”, firmă care prin delegatul ei își ia mărinimos angajamentul că în cazul când, în cursul exploatării se va descoperi ceva arheologic, va comunica Prefecturii".

De fapt, Muzeul Național de Antichități ce am onoarea să conduc n'a făcut nicio săpătură la Topalu, ci printr-un delegat al său, d. Florescu, profesor secundar și asistent universitar, a căutat doar să vadă cum se găsește cetatea, de nu s'a mai descoperit ceva și cum se face exploatarea carierelor de acolo, din punctul ce ne privește și suntem datori a-l reprezenta, acela al intereselor arheologice. Nu numai că delegatul nostru n'a/ făcut la Topalu nicio săpătură, dar nici informațiunile necesare nu le-a putut lua, fiind tratat de numitul d. reprezentant al Firmei Cantacuzino cu o brutalitate de cea mai josnică ordine. Aceasta ne-a îndemnat să reclamăm și să apelăm la Ministerul de Interne, care însă prin organele sale locale a apreciat că e cazul să ia numai asigurări pentru viitor - și acestea insuficiente, dat fiind persoana ce le-a produs trecând cu vederea că faptul petrecut este o insultă adusă delegatului nostru în exercițiul funcțiunii și aplicarea Legei pentru conservarea și restaurarea monumentelor istorice publicată în Mon.Of. No 82 din 29 Iulie 1919. 
Concluzii:

Cetatea de la Topalu există. Răposatul Profesor și Director V. Pârvan o menționează repetat în lucrările sale române și străine şi a publicat lucruri însemnate găsite acolo; tot el notează protestele zadarnice ce s'au făcut față de exploatarea carierelor de acolo. În timp ce Ministerul de Industrie și Comerț ne asigură că a luat măsuri de a o protegiu - lucru pentru care i'am fi cu totul recunoscători, prin Ministerul de Interne/ aflăm „că se exploatează cariera în aer liber”, că de cetate nu se știe acolo aproape deloc.

Carierele de peatră dela Topalu sunt exploatate fără nici o știință că acolo ar fí o cetate și evident, fără nici o cruțare. Delegatul nostru n'a putut culege nici cele mai simple informații, fiind insultat în exercițiul misiunii sale publice și științifice. În aceste condițiuni, mai poate fỉ serios vorba, că Direcțiunea Muzeului Național de Antichități a vândut peatră extrasă dela descoperirea cetății, descoperire pe care n'a făcut'o, de fapt, niciodată?

Delegatul nostru, dl Florescu a săpat în județul Constanța, încă din 1924, cu o întrerupere de 2 ani, dar la Calachioi, care prin expropriere a trecut cu teritoriul ei în proprietatea Muzeului Național de Antichități, situație în care este clar că nu cade în prevederile nici unui articol din Legea Minelor.

Într'un scurt răstimp, și la strictă necesitate a conducerii săpăturilor de la Capidava, d. Florescu a cedat dela săpăturile acestei cetăți, piatră din moluzul și pământul deslocat de lângă zidurile cetății unora dintre locuitorii satului Calachioi în schimbul lucrului la săpătură. În tot cazul aceasta s'a făcut cu aprobarea Direcțiunii Muzeului, în spirit de economie şi bună administrație.

Astfel fiind lucrurile față de situația mai sus prezentată, vă rugăm deci, Dle Președinte, să binevoiţi a interveni din nou atât la Ministerul de Interne, cât și la acela de Industrie/ și Comerț.

1. Pentru o nouă anchetă la Topalu, la care să participe și un delegat al Muzeului nostru, indicat a da toate lămuririle trebuitoare pentru o asemenea cercetare. Numai după încheierile ei, să se ia în adevăr măsurile de apărare, în conformitate cu Legea Minelor.

2. Onor. Ministerul de Interne prin organele sale să fie informate încă odată despre faptele administratorului carierelor din Topalu, care să fie tras la răspundere pentru ceiace s'a făcut vinovat, împiedicând cu brutalitate aplicarea legilor în vigoare. Îndeosebi să se atragă atenţiune organelor locale, ca să dea o mai deaproape atenție, obiectivă și desinteresată chestiunilor de însemnătate generală istorică.

3. Să se încunoștințeze Onoratul Minist. de Industrie și Comerț că Direcțiunea Muzeului Național de Antichităţi n'a vândut nici un fel de peatră dela descoperirea cetății dela Topalu, descoperire pe care n'a făcut'o încă, și n'a călcat astfel nici o lege. 


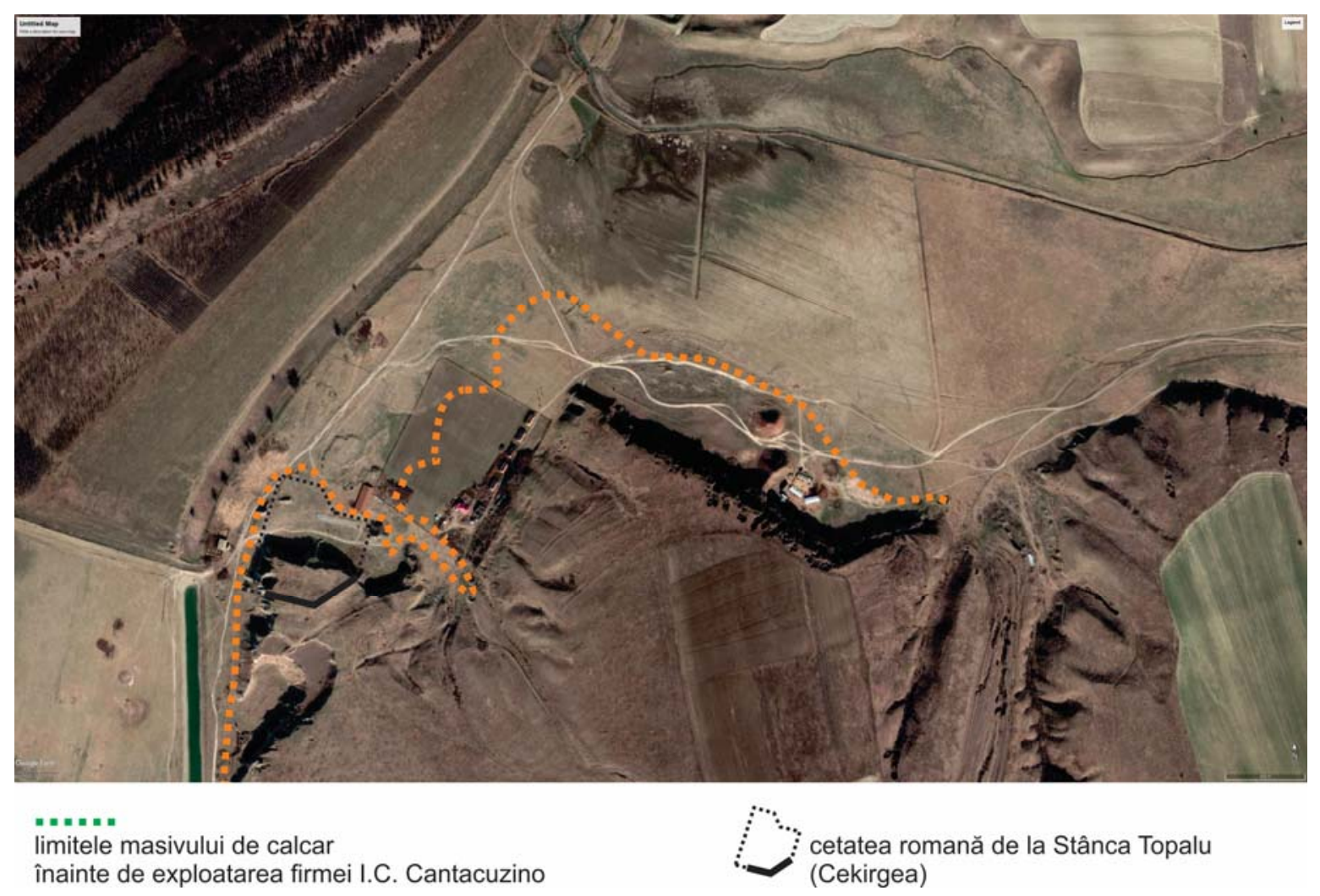

Ilustraţie suplimentară: Reconstituirea limitelor masivului de calca pe care este ridicat fortul.

Supplementary illustration: Reconstruction of the limits of the limestone masiff on wich the fort is raised. 